\title{
Metal Oxide Nanoparticles and their Nanocomposite- based Materials as Photocatalysts in the Degradation of
} Dyes

\author{
Naveen Chandra Joshi ${ }^{1, *(\mathbb{D})}$, Prateek Gururani ${ }^{2}$ (I) , Shiv Prasad Gairola ${ }^{1(\mathbb{D})}$

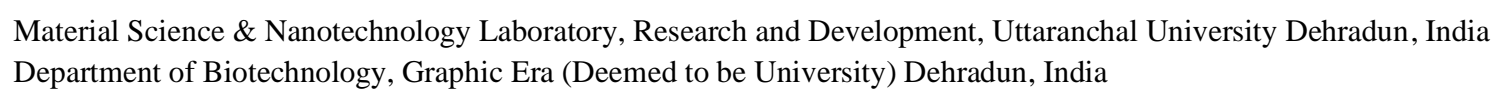

Scopus Author ID 57200496551

Received: 11.06.2021; Revised: 20.09.2021; Accepted: 25.09.2021; Published: 19.11.2021

\begin{abstract}
The introduction of inorganic and organic pollutants into water bodies has become a serious issue globally. The waste streams released from the textile, plastic, leather, paper, pharmaceutical, and food industries introduce different natural and synthetic dyes into the aquatic system. Nanomaterials play a significant role in the photocatalytic degradation of dyes present in wastewater. Inorganic metal oxide nanoparticles have many improved physical and chemical properties and attracted much attention in photocatalytic activities. Dyes have been released in our aquatic bodies due to many anthropogenic activities and caused life-threatening problems. Various conventional methods were reported to remove dyes from water and wastewater; the photocatalytic method is one of the efficient and cost-effective. The present review article includes detailed information on photocatalysis, the potential of metal oxide and their composite materials as photocatalysts in the degradation of toxic dyes, and some common synthetic and characterization methods used for metal oxide-based nanoparticles.
\end{abstract}

Keywords: wastewater; dyes; photocatalytic activity; metal oxide nanoparticles; composite materials of metal oxide nanoparticles.

(C) 2021 by the authors. This article is an open-access article distributed under the terms and conditions of the Creative Commons Attribution (CC BY) license (https://creativecommons.org/licenses/by/4.0/).

\section{Introduction}

Nanotechnology is the practice of nano-scaled objects in different fields of science and engineering. In general, the nano-scaled objects contain particle sizes from 1 to $100 \mathrm{~nm}$, and nanotechnology provides their design, synthesis, characterization, and utilization for different purposes. The nanomaterials have been designed with their highly specific and controlled physical and chemical characteristics [1]. Since the last decades, very remarkable interest has been developed to synthesize and utilize nano-scaled materials [2]. The inorganic metal oxide nanoparticles attracted great attention due to their advanced physical and chemical characteristics. Metal oxide nanoparticles were considerably utilized in medicine, material chemistry, information technology, electronics, and catalysis, energy, sensors, and environmental remediation, optical, pharmaceutical, and biological sciences. Some common applications of metal oxide nanoparticles are illustrated in Figure 1. The common metal oxide nanoparticles such as $\mathrm{CuO}, \mathrm{MnO}_{2}, \mathrm{SnO}_{2}, \mathrm{TiO}_{2}, \mathrm{ZnO}, \mathrm{ZrO}_{2}$, and $\mathrm{CeO}_{2}$ have been utilized in different fields of science and technology. The properties of magnetic metal oxide nanoparticles are generally based on their shape and sizes and the specific type of materials used in their synthesis [3-7]. The nanocomposite materials based on metal oxide nanoparticles 
are of a diverse class of materials in terms of electromagnetics, physical, chemical, and other properties. The successful utilization of such nanocomposite materials in adsorption and photocatalysis is due to their large surface area, good pollutants loading capacity, a specific affinity for various contaminants, and fast kinetics. As photocatalysts, metal oxide nanoparticles and their composite materials are used to degrade non-decomposed contaminants from water and wastewater [8]. Water pollution due to inorganic and organic pollutants has become a very sensitive issue in the world. Anthropogenic activities such as urbanization, industrialization, fossil fuel combustion, and others release the inorganic and organic-based pollutants into aquatic bodies.

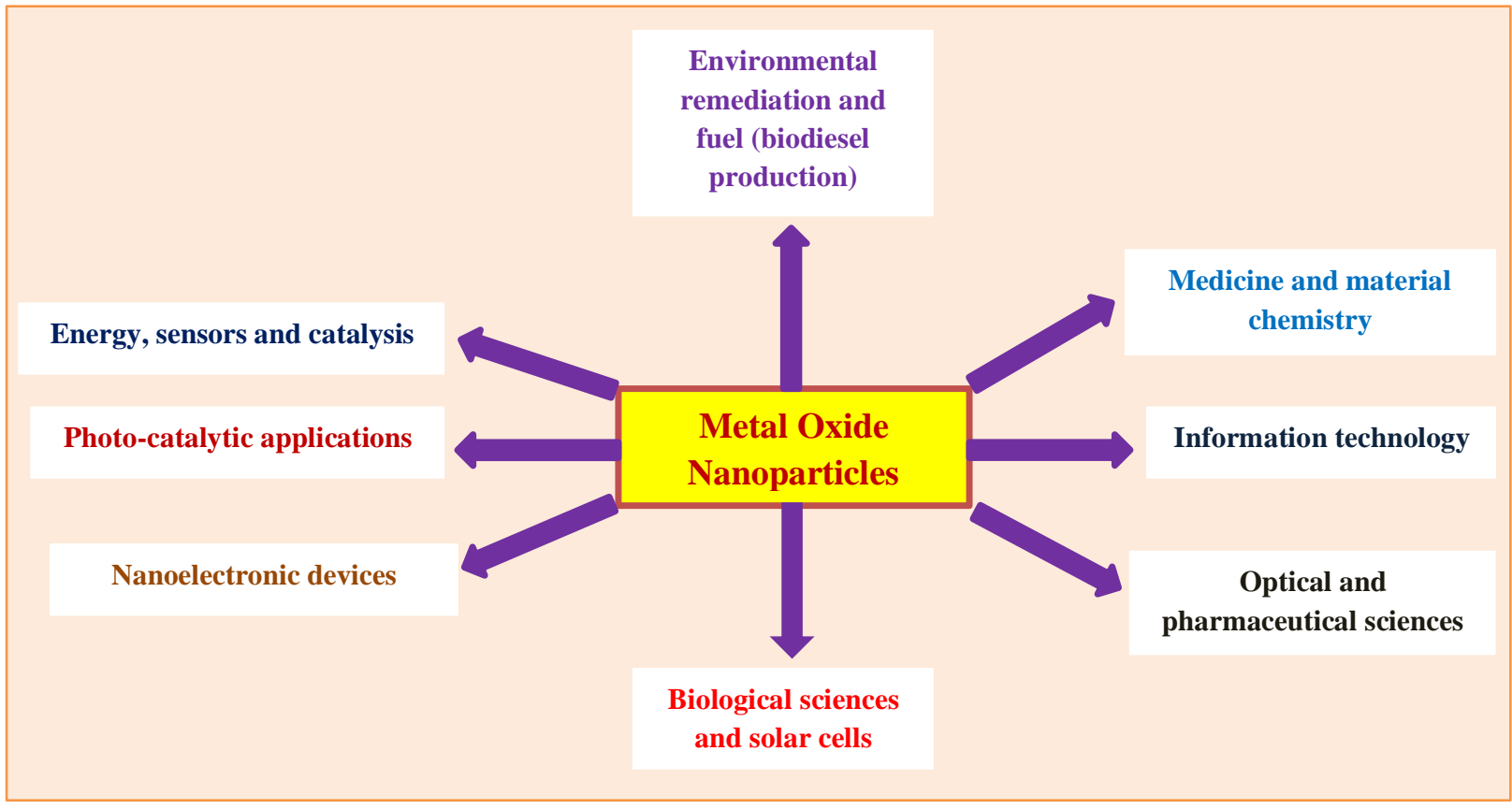

Figure 1. Common applications of metal oxide nanoparticles.

The dyes are used in plastic, leather, paper, pharmaceutical, food, and textile industries and ultimately released into fresh and saline water. The dyes are water-soluble organic species; dyes and their metabolites are definitely harmful to humans and other living organisms $[9,10]$. Due to high water solubility, they are very difficult to remove from water and wastewater. Dyes are generally used in the textile and food processing industries and released through their waste streams. In general, the waste stream of such industries contains bleaching agents, finishing chemicals, thickening agents, surface-active chemicals, metallic salts, and dyestuffs. Most dyes cause irritations, eye damage, dizziness, sweating, nausea, skin discoloration, headache, and other health problems [11-18]. Dyes may be natural or synthetic; the natural dyes are mainly derived from minerals, insects, and plants. The synthetic dyes are water-soluble, waterinsoluble, and in-situ color formation. According to chemical nature, the synthetic dyes are classified into sulfur, anthraquinone, phthalocyanine, triarylmethane, and azo, whereas according to their mode of application, they may be direct dispersed, basic, reactive, and vat types $[18,19]$. According to the presence of chromophore, the textile dyes are categorized as nitrated, phthalein, triphenyl methyl, nitro, azo indigo, anthraquinone etc. [20]. The dye waste stream released from different industries shows high color intensity, $\mathrm{pH}$, suspended solids, metallic species, and their salts and high chemical oxygen demand (COD), biological oxygen demand (BOD), and temperature [19-24]. The reported methods such as membrane filtration, oxidation, photodegradation, adsorption, biodegradation, and other physical and chemical have 
been successfully used to remove dyes from aqueous solutions [10, 25-29]. The photocatalytic methods are efficient, low cost, and very effective using nano-based materials as photocatalysts [30-33]. This review article discusses detailed information of photocatalysis, the potential of metal oxide and their composite materials, some common synthetic approaches, and characterization techniques of metal oxide nanomaterials.

\section{Photo-Catalysis and its Mechanism}

Catalysts are generally used to speed up chemical reactions; photocatalysts are utilized to speed up chemical reactions in the presence of ultra-violet (UV) and visible lights. The photocatalytic system is characterized by sufficient bandgap, stability, adequate morphology, high surface area, and reusability [34]. There are two types of photocatalytic reactions, i.e., homogeneous and heterogeneous photocatalytic reactions. The photocatalytic reagents are largely used to degrade or mineralize hazardous materials into $\mathrm{CO} 2$ and $\mathrm{H} 2 \mathrm{O}$, deactivation and destruction of microorganisms, decomposition of air pollutants, and degradation of waste plastics. The metal oxide nanoparticles and their composite materials are well known for their photocatalytic behavior in the presence of UV radiation [35,36]. The photocatalysis on the surface of metal oxide nanoparticles is mediated by valence and conduction bands. The valence and conduction bands are regarded as holes and electrons. Electrons are shifted from valence to conduction band through a proper bandgap in the presence of UV light (Figure 2). The transfer of electrons results in oxidation and reduction. Ultimately this process is leading the formation of reactive oxygen species (ROS). ROS is usually responsible for the degradation of dyes (Scheme 1) [36-43]. Finally, photocatalysis is related to oxidation and reduction processes on the surface of any metal oxide and its composite material. The process is mediated by valence bands (VB) such as holes ( $\mathrm{h}+$ ) and conduction bands (CB) such as electrons (e-) which are generated by the absorption of ultra-violet light. The photo-generated pairs of $\mathrm{h}+$ and eaccelerate the formation of highly aggressive species, i.e., hydroxyl $\left(\mathrm{OH}^{-}\right)$or superoxide radicals from the moisture and atmospheric oxygen. Such species are sufficient to oxidize and decompose organic materials or smell gas and destroy bacteria [37].

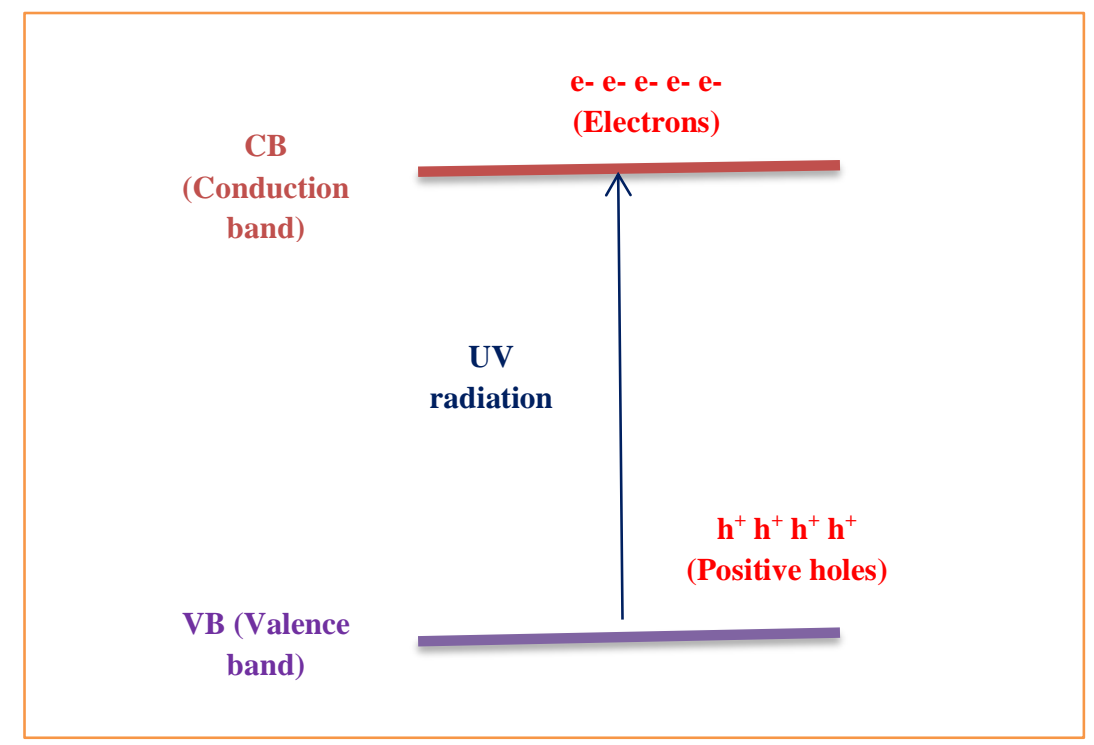

Figure 2. Shifting of electrons from valence to conductance band. 


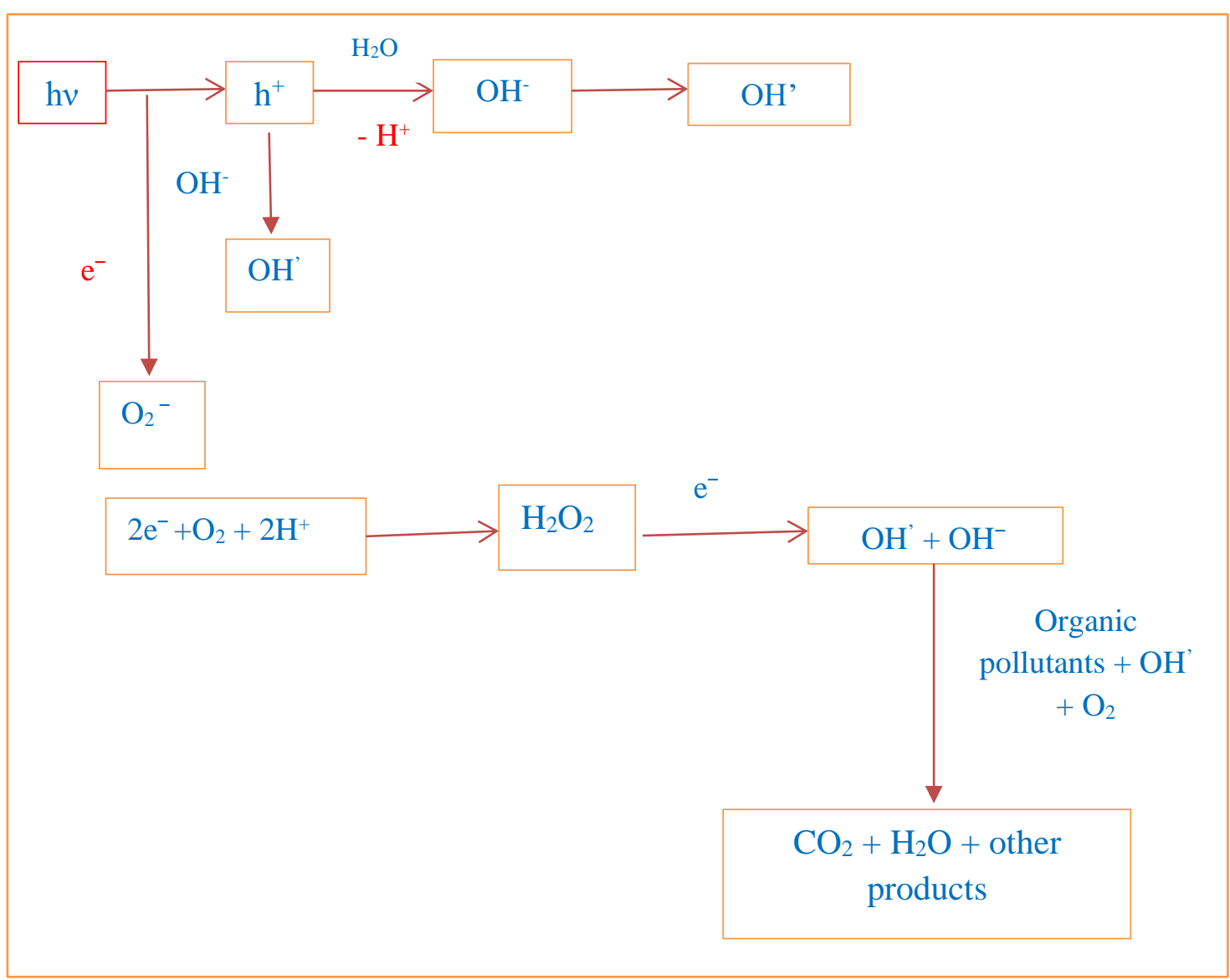

Scheme 1. Schematic representation of photodegradation of organic dyes.

Photocatalysis is an efficient process for the degradation of organic substances, microbial disinfection, and mineralization of hazardous compounds due to the formation of $\mathrm{OH}-$ ions (strong oxidizing agent). If the reaction occurs in the presence of oxygen and water, the electron in the conduction band is picked up by oxygen and gives rise to a superoxide radical anion; water is oxidized into $\mathrm{OH}$ radical on the oxidation site. The formation of these two reactive species results in the complete mineralization of organic pollutants and reactions $\mathrm{e}-\mathrm{h}+$ pair with different electron donors and acceptors. Further, the redox potentials of valence and conduction band are sufficiently positive and negative for the generation of $\mathrm{OH}$ - and superoxide radicals $[16,44,45]$.

\section{Metal Oxide Nanoparticles as Photocatalysts}

The transition metals and their oxides have been used in different catalytic activities. They show many special properties and industrial applications. They can also behave as superconducting materials, ceramics, crystalline lasers, photoactive materials, photosensitizers, sensors, etc. Metal oxides have played a significant role in the areas of physical, chemical and materials sciences. The metal oxides can easily be synthesized and are multifunctional [46]. Metal oxides have also been potentially utilized in environmental remediation, energy production, storage, and conversion. They exhibit advanced and different functional properties due to crystalline structure, morphology, doping, intrinsic defects, and composition [47-49]. 


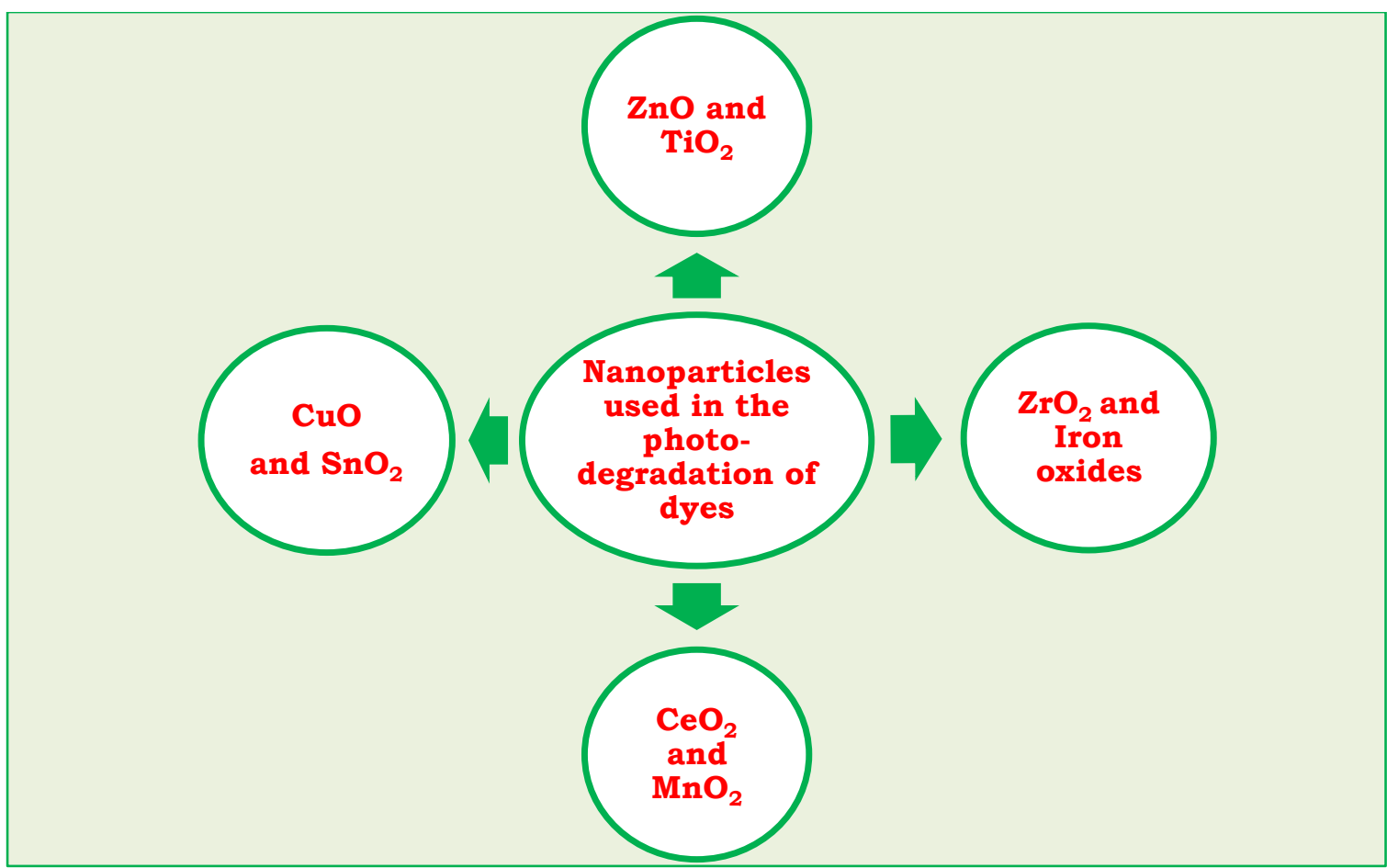

Figure 3. Common metal oxide nanoparticles used in the photocatalytic degradation of dyes.

In general, when metal oxide nanoparticles having wide-bandgap are irradiated with light energy, the positive hole-electron pairs are formed; substrates may adsorb on the surface of photocatalyst and react directly or indirectly with the generated holes and electrons [50]. Metal oxide nanoparticles (Figure 3) have been reported to degrade the organic pollutants and toxic inorganic substrates into readily degradable compounds even mineralize them into less harmful carbon dioxide and water [51]. The reported metal oxide nanoparticles (MO NPs) were utilized in the degradation of different dyes given as below:

\subsection{ZnO Nanoparticles (ZnO NPs).}

Zinc oxide $(\mathrm{ZnO})$ is a white powder and commonly used in ceramics, glass, cement, rubber (e.g., car tires), lubricants, paints, ointments, adhesives, plastics, sealants, pigments, foods (source of $\mathrm{Zn}$ nutrient), batteries, ferrites, and fire retardants. $\mathrm{ZnO}$ nanoparticles ( $\mathrm{ZnO}$ NPs) are potentially used in cosmetics, textiles, microelectronics, catalysts, semiconductors, antimicrobial agents, photocatalysis, and environmental remediation. Due to stability, direct wide gap, and large binding energy at normal temperature, ZnO NPs are used as photocatalysis, solar cells, and light-emitting diode [52,53]. Tayeb and others [54] studied the applications of $\mathrm{ZnO}$ NPs in the photodegradation of methylene blue from the aqueous solution. After UV irradiation time of $90 \mathrm{~min}, 97 \%$ methylene blue was degraded in the presence of ZnO NPs. The photocatalytic activity of ZnO NPs was reported by Bibi et al. [55] under UV irradiation to degrade Remazol brilliant blue. Maximum dye degradation was found as $85.91 \%$ at irradiation time 60 min. Rodrigues and other workers [56] studied the applicability of ZnO NPs in the photocatalytic degradation of RB 19 and RB 21 dyes under UV light and found the efficiency of photodegradation as $100 \%$ and $91 \%$ after $6 \mathrm{hrs}$ for RB 19 and RB. They observed that the photocatalytic activity was highly affected by dye concentration, length to diameter ratio of photoreactor, and catalyst size. Maureen and others [57] reported using ZnO NPs to degrade malachite green dye under UV light. The maximum percentage photodegradation of dye has 
been achieved as $96.31 \%$ at dosage $0.5 \mathrm{~g}$ and irradiation time $150 \mathrm{~min}$. They studied the kinetics of degradation and found the suitability of the pseudo-first-order kinetic model.

\subsection{Titanium dioxide nanoparticles $\left(\mathrm{TiO}_{2} \mathrm{NPs}\right)$.}

Titanium dioxide nanoparticles $\left(\mathrm{TiO}_{2} \mathrm{NPs}\right)$ have been synthesized for different applications such as photocatalysis, solar cell, antibacterial agents, and wastewater treatments. These are easily available, low toxic, and cost-effective $[58,59] . \mathrm{TiO}_{2} \mathrm{NPs}$ are very effective photocatalysts due to their unique electronic and optical properties, chemical stability, and sufficient bandgap and are capable of degrading the inorganic and organic pollutants [60-62]. Gautam and others [63] investigated the effect of anatase and rutile $\mathrm{TiO}_{2} \mathrm{NPs}$ on the degradation of methylene blue under short ultra-violet irradiation. The maximum percentage degradation of anatase and rutile $\mathrm{TiO}_{2} \mathrm{NPs}$ were obtained as $88 \%$ and $77 \%$ for methylene blue. Kaur et al. [64] studied the potential use of green synthesized $\mathrm{TiO}_{2} \mathrm{NPs}$ (using Carica papaya leaves extract) to degrade RO-4 dye under ultra-violet radiation. The percentage of dye degradation was found at $91.19 \%$ within 180 min. Khade and other co-workers [65] showed that the anatase $\mathrm{TiO}_{2}$ NPs were capable of degrading the methyl orange from an aqueous solution under ultra-violet radiation. More than $93 \%$ dye was degraded within $150 \mathrm{~min}$. Nabi et al. [66] used the green synthesized (using Lemon extract) $\mathrm{TiO}_{2} \mathrm{NPs}$ to degrade Rhodamine $\mathrm{B}$ under UV-Visible radiation. The experimental results showed that the $\mathrm{TiO}_{2} \mathrm{NPs}$ were highly capable of degrading Rhodamine B from the aqueous solution.

\subsection{Zirconium oxide nanoparticles $\left(\mathrm{ZrO}_{2} \mathrm{NPs}\right)$.}

Zirconia nanoparticles $\left(\mathrm{ZrO}_{2} \mathrm{NPs}\right)$ show many advanced properties, i.e., excellent color, good strength, high chemical stability, corrosion resistance, and microbial and chemical resistance. $\mathrm{ZrO}_{2}$ NPs exist in cubic, tetragonal, and monoclinic phases under normal pressure and different temperatures. The monoclinic $\mathrm{ZrO}_{2}$ phase is stable up to $1100^{\circ} \mathrm{C}$, the tetragonal $\mathrm{ZrO}_{2}$ phase exists in the temperature range of $1100-2370^{\circ} \mathrm{C}$, and the cubic phase is found at higher temperature (above $2370^{\circ} \mathrm{C}$ ) [67-69]. Mansouri et al. [70] studied the use of $\mathrm{ZrO}_{2} \mathrm{NPs}$ to degrade methyl orange under ultra-violet light and observed more than $97 \%$ dye degradation during $80 \mathrm{~min}$. Basahel and others [71] reported the use of monoclinic $\mathrm{ZrO}_{2} \mathrm{NPs}$ in the removal of methyl orange from aqueous solution in the presence of ultra-violet radiation; more than 95\% dye was degraded within $110 \mathrm{~min}$. Saeed et al. [72] studied the palladium and platinumsupported $\mathrm{ZrO}_{2} \mathrm{NPs}$ in the photodegradation of indigo disulfonate; they observed the percentage degradation as $96 \%$ and $94 \%$ for indigo disulfonate in the presence of $\mathrm{Pd}$ and $\mathrm{Pt}$ supported $\mathrm{ZrO}_{2} \mathrm{NPs}$ within $14 \mathrm{~h}$.

\subsection{Iron oxide nanoparticles.}

The iron oxide nanoparticles (IONPs) show many unique properties such as larger surface area, super-paramagnetism, high surface to volume, and easily separable. IONPs have been widely used in agriculture, environmental remediation, and biomedicines. The most common IONPs are magnetite $\left(\mathrm{Fe}_{3} \mathrm{O}_{4}\right)$, maghemite $\left(\gamma-\mathrm{Fe}_{2} \mathrm{O}_{3}\right)$, and hematite $\left(\alpha-\mathrm{Fe}_{2} \mathrm{O}_{3}\right)$ nanoparticles [73]. Parhizkar and Habibi [74] studied the use of $\alpha-\mathrm{Fe}_{2} \mathrm{O}_{3}$ nanoparticles in the photocatalytic degradation of reactive red 4 (RR4) dye under ultra-violet light. The experimental results showed that $52 \%$ of dye degradation was found in $135 \mathrm{~min}$. Długosz et al. [75] reported the enhanced photocatalytic activity of $\mathrm{ZnO}$ NPs after incorporation with $\mathrm{Fe}_{3} \mathrm{O}_{4}$ 
nanoparticles. The maximum percentage photodegradation of this material was found at 95.61 $\%$ for trypan blue and $63.02 \%$ for methylene blue. Alagiri and Hamid [76] considered the potential application of $\alpha-\mathrm{Fe}_{2} \mathrm{O}_{3}$ nanoparticles in the degradation of methylene blue under UV radiation. The results showed that more than $90 \%$ degradation of methylene blue was recorded in the presence of UV radiation and $\alpha-\mathrm{Fe}_{2} \mathrm{O}_{3}$ nanoparticles. Rincon Joya and others [77] used the $\alpha-\mathrm{Fe}_{2} \mathrm{O}_{3}$ nanoparticles to degrade Rhodamine $\mathrm{B}$ and atrazine under ultra-violet radiations. Within 40 min, the percentage degradation of $59 \%$ for atrazine and $40 \%$ for Rhodamine B were achieved.

\subsection{Cerium oxide nanoparticles $\left(\mathrm{CeO}_{2} \mathrm{NPs}\right)$.}

Cerium dioxide $\left(\mathrm{CeO}_{2}\right)$ or ceria is the most stable oxide of cerium and the second reactive member of the lanthanide series. The +4 oxidation state of cerium in $\mathrm{CeO}_{2}$ is responsible for its higher stability. $\mathrm{CeO}_{2}$ nanoparticles $\left(\mathrm{CeO}_{2} \mathrm{NPs}\right)$ are basically used in biomedicine, drug delivery, bio scaffolding, environment, and different biological activities [78]. Pouretedal and Kadkhodaie [79] studied the applicability of $\mathrm{CeO}_{2}$ nanoparticles in the degradation of methylene blue from the aqueous system under UV-Visible irradiation. The highest degradation was obtained with $1.0 \mathrm{~g} / \mathrm{L} \mathrm{CeO}_{2}$ at $\mathrm{pH} 11$ within $125 \mathrm{~min}$. Majumder and other workers [80] reported the complete degradation of methylene blue from textile effluents using $\mathrm{CeO}_{2}$ NPs under UV-Visible radiation within 175 minutes. Ravishankar et al. [81] studied the photodegradation of trypan blue in the presence of UV light and $\mathrm{CeO}_{2} \mathrm{NPs}$. About $100 \%$ dye degradation was observed within 135 minutes from the aqueous system.

\subsection{Manganese dioxide nanoparticles $\left(\mathrm{MnO}_{2} \mathrm{NPs}\right)$.}

Manganese dioxide $\left(\mathrm{MnO}_{2}\right)$ is also known as pyrolusite and is used in ceramic industries, glassmaking, batteries, etc. $\mathrm{MnO}_{2}$ nanoparticles $\left(\mathrm{MnO}_{2} \mathrm{NPs}\right)$ generally possess a unique 2D structure used in biomedicine, fluorescence sensing, magnetic resonance imaging, and cargo-loading functionality [82]. Rahmat et al. [83] used the $\mathrm{MnO}_{2} \mathrm{NPs}$ to degrade crystal violet from wastewater under visible light. After $90 \mathrm{~min}$, the percentage degradation of the dye was achieved as $97 \%$. Khan and others [84] used the activated carbon incorporated with $\mathrm{MnO}_{2}$ NPs for the photodegradation of Congo red (CR) dye from aqueous solutions. This material was capable of degrading $98.53 \%$ of Congo red dye within 5 min. Chan et al. [85] were reported the utilization of $\mathrm{MnO}_{2} \mathrm{NPs}$ in the degradation of Rhodamine B from aqueous effluent under visible light. The percentage degradation of $90.3 \%$ was found at an irradiation time of $120 \mathrm{~min}$. Hamza [86] utilized the $\mathrm{MnO}_{2} \mathrm{NPs}$ in the photochemical removal of alizarin red (AR) dye from wastewater using ultra-violet light and found the maximum percentage degradation of $80 \%$.

\subsection{Cupric oxide nanoparticles ( $\mathrm{CuO} N \mathrm{NP}$ ).}

Copper (II) oxide nanoparticles (CuO NPs) are brownish-black colored with a narrow bandgap and generally monoclinic structure. They have interesting properties such as good thermal conductivity, high stability, good selectivity, photo-voltaic properties, and antimicrobial activities. CuO NPs can also be used in ceramics, magnetic storage media, gas sensors, and high-tech superconductors [87-92]. Singh et al. [93] utilized the green synthesized $\mathrm{CuO}$ NPs (using Psidium guajava leaves extract) for the photodegradation of Nile blue and yellow 60 in an aqueous solution. Within $120 \mathrm{~min}$, 93\% of Nile blue and $81 \%$ of yellow 60 were degraded. Sharma and Dutta [94] reported the highly stable CuO NPs with valence band 
edge $(2.59 \mathrm{eV})$ and conduction band edge $(0.29 \mathrm{eV})$ and used such nanoparticles in the degradation of acid orange-74 dye under ultra-violet radiations. They found the CuO NPs had excellent photocatalytic dye degradation ability. Narasaiah et al. [95] have synthesized the $\mathrm{CuO}$ NPs using the leaves extract of Drypetes sepiaria and found their excellent photocatalytic activity in the degradation of Congo Red. Chauhan and others [96] studied the utilization of $\mathrm{CuO}$ NPs in the photodegradation of Victoria Blue (VB) and Direct Red 81 (DR 81) from the aqueous effluent and observed the percentage degradation of more than $96 \%$.

\subsection{Tin oxide nanoparticles $\left(\mathrm{SnO}_{2} \mathrm{NPs}\right)$.}

Tin oxide $\left(\mathrm{SnO}_{2}\right)$ is an n-type semiconductor with a bandgap of $3.6 \mathrm{eV}$ at ordinary temperature. $\mathrm{SnO}_{2}$ nanoparticles $\left(\mathrm{SnO}_{2} \mathrm{NPs}\right)$ show good optical and electrical properties at room temperature, photocatalytic activity, and low resistivity. $\mathrm{SnO}_{2} \mathrm{NPs}$ are also used in the coating, photo-voltaic, photo-sensors, gas sensors, etc. [97-101]. Selvaraj and Roopan [102] reported the utilization of biologically synthesized $\mathrm{SnO}_{2}$ NPs (using methanolic extract of Cyphomandra betacea) in the photodegradation of methylene blue present in aqueous effluent. The rod-shaped $\mathrm{SnO}_{2}$ NPs with particle size $21 \mathrm{~nm}$ were found excellent photocatalyst to degrade methylene blue in the effluent. Tammina et al. [103] utilized the $\mathrm{SnO}_{2} \mathrm{NPs}$ to degrade methylene blue under the ultra-violet radiations. The smaller-sized $\mathrm{SnO}_{2} \mathrm{NPs}$ exhibited a higher rate of degradation within $30 \mathrm{~min}$. Li et al. [104] considered the photocatalytic applications of $\mathrm{SnO}_{2}$ NPs in the degradation of methylene blue and Rhodamine B present in the aqueous effluent. More than $90 \%$ methylene blue and Rhodamine B were degraded under UV light irradiation within $50 \mathrm{~min}$ and $270 \mathrm{~min}$, respectively. Viet et al. [101] used the $\mathrm{SnO}_{2}$ NPs (synthesized using the hydrothermal method) to degrade methylene blue under sunlight. The smaller-sized $\mathrm{SnO}_{2}$ NPs degraded $90 \%$ methylene blue within 120 min. Titus and Samuel [105] applied the green synthesized $\mathrm{SnO}_{2}$ NPs (using methanolic extract of Arachis hypogaea) to degrade Congo red under ultra-violet light; $89 \%$ degradation was recorded after $50 \mathrm{~min}$.

\section{Some Common Synthetic Approaches Used in the Synthesis of Metal Oxide Nanoparticles}

Based on choice of the medium, the basic synthetic methods used to synthesize metal oxide nanoparticles are generally categorized into liquid phase, biological/green, and vapor state-based methods (Figure 4). The selection of synthetic methods determines many physical and chemical characteristics of metal oxide nanoparticles. These properties include particle size, crystal appearance, and shape of particles, dispersity, and type of intrinsic or extrinsic defects [106-109]. The methods mentioned above are shortly explained as below:

\subsection{Liquid phase-based synthetic methods.}

\subsubsection{Colloidal methods.}

The colloidal-based methods are based on the mixing of solutions containing different ions under controlled temperature and pressure. As a result, an insoluble precipitate of nanoparticles is formed and easily separable. These methods are frequently used to synthesize metal, metal oxide, organics, and other nanoparticles [110-112]. 


\subsubsection{Sol-gel methods.}

Sol-gel methods are widely used and well-established methods; such methods are used for materials having novel and predefined properties. These methods are based on the interactions between sol (containing solid particles) and the gel (containing solid macromolecule). The major step of this method is the hydrolysis of precursors (especially metal-organic compounds) $[113,114]$.

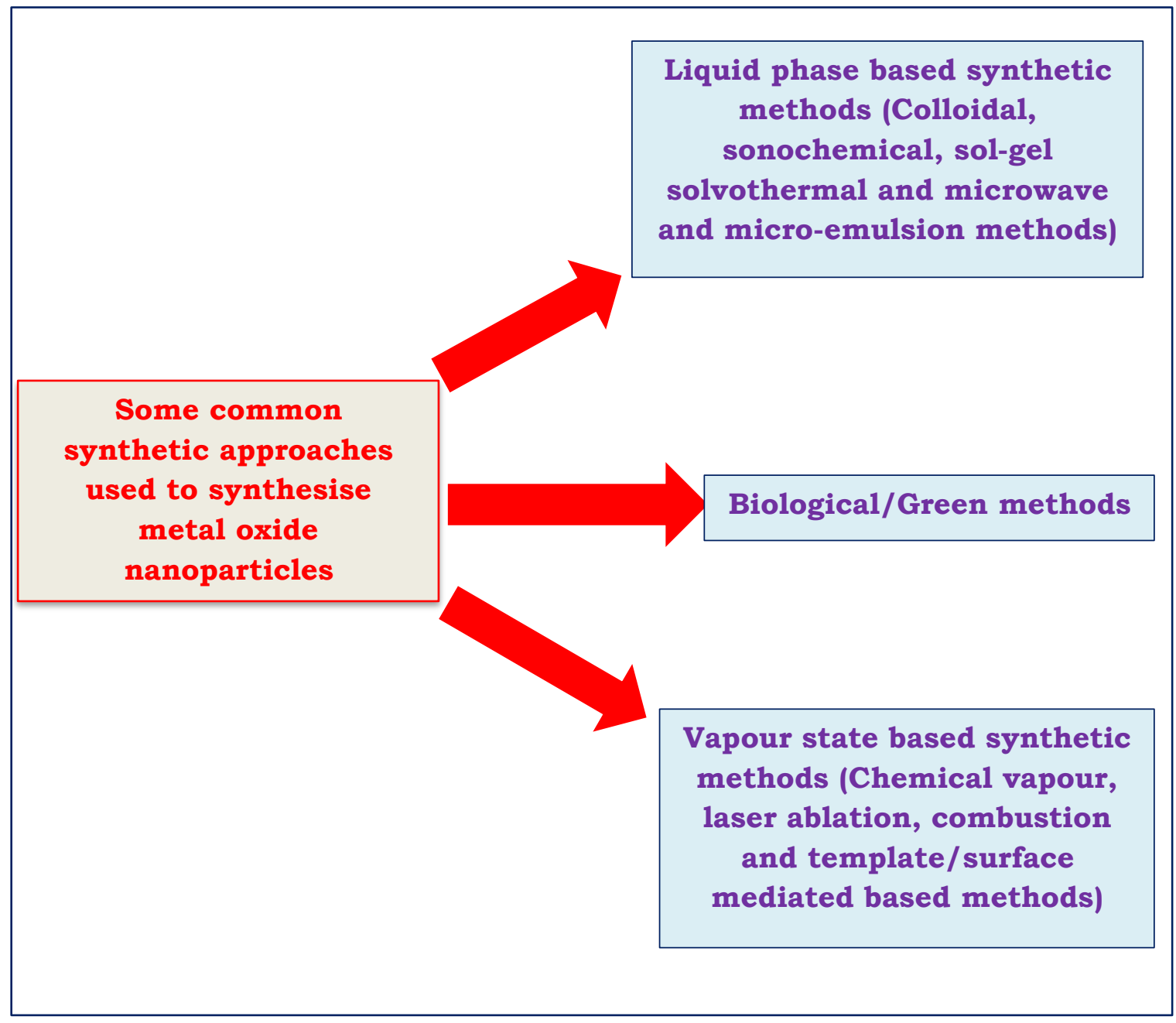

Figure 4. Some commonly used methods for the synthesis of metal oxide nanoparticles.

\subsubsection{Sonochemical method.}

In such methods, the starting materials are contacted with ultrasonic vibrations for the breaking of chemical bonds. The ultrasonic waves pass through the solution and cause compression and relaxation; it causes acoustic cavitation. Ultimately, thousands to million bubbles undergo collapsing, and a large amount of energy is released into the solution [115117].

\subsubsection{Solvothermal method.}

Solvothermal methods have been used to synthesize different nano-based materials, including metal oxide-based materials, by dispersing the precursors into a suitable solvent and then applying moderate temperature and pressure. If the medium is water, then this method is 
called a hydrothermal method. This method is dependent on the nature of starting material, composition, ratio, and thermodynamic parameters [10,118].

\subsubsection{Microemulsion method.}

The microemulsion method consists of two different immiscible phases, which are separated through the surfactant molecules. In this method, a mixture of metallic precursors, oil, water, and surfactants are used and subjected to stirring at ordinary temperature to prepare a homogeneous phase $[119,120]$.

\subsubsection{Microwave-assisted method.}

The microwave-assisted method is needed very low energy and time; the faster reactions can be performed with high heating rates without any temperature gradient. The mechanism of the synthetic reaction is based on ionic conductivity and polarization. The speed of reactions involving nanomaterials' preparation favors nucleation and highly dispersed particles $[121,122]$.

\subsection{Vapor state synthesis.}

\subsubsection{Laser ablation method.}

The laser ablation technique is generally used to generate nanoparticles through the irradiation of colloidal solutions originating from the bulk materials in water or other solutions. The particles size is dependent on the laser fluence and nature of the liquid medium. This technique is used to synthesize noble stable nanoparticles and does not require stabilizing molecules or chemicals $[123,124]$.

\subsubsection{Combustion method.}

Combustion methods are highly efficient and energy-saving and can be proceeded in solid, liquid, and gas phases. This method is also called self-propagating high-temperature synthesis and is very common to synthesize metal oxide nanoparticles. Combustion methods initially can take place through the solid, liquid, and gas-phase combustions. The maximum synthesis temperatures are limited by the thermodynamics of the systems [81, 125].

\subsubsection{Template synthesis.}

The template methods involve the control of crystal growth and nucleation, and the synthetic route is divided into three steps. The first step is the preparation of the template; the second is the applicability of suitable synthetic approaches such as sol-gel, precipitation, hydrothermal, etc. The final step is the removal of the template. The templates may be natural or synthetic; the natural templates include biological molecules, minerals, tissues, etc. The artificial templates include porous materials, nanoparticles, surface-active agents, etc. $[126,127]$.

\subsection{Biological or green methods.}

The biological or green synthetic approaches used in synthesizing metal oxide nanoparticles have gained much attention due to their efficiency, low cost, and being 
environmentally friendly. The main advantages of greener methods are minimizing waste, reducing unnecessary derivatives, simplicity, and no requirement of toxic chemicals. The biological extracts containing different secondary metabolites generally obtained from plants, algae, fungi etc. are used as reducing, capping, or stabilizing agents during the synthesis of different metal and metal oxide nanoparticles [128-131].

Table 1. Some metal oxide nanoparticles synthesized using different synthetic methods.

\begin{tabular}{|c|c|c|}
\hline Metal oxide nanoparticles & Methods used for synthesis & References \\
\hline $\mathrm{TiO}_{2} \mathrm{NPs}_{\mathrm{S}}$ & Colloidal & [110] \\
\hline $\mathrm{TiO}_{2}$ NPs & Colloidal & [111] \\
\hline $\mathrm{SnO}_{2} \mathrm{NPs}$ & Colloidal & [112] \\
\hline ZnO NPs & Sol gel & [113] \\
\hline ZnO NPs & Sol gel & [114] \\
\hline $\mathrm{ZrO}_{2} \mathrm{NPs}$ & Sonochemical & {$[115]$} \\
\hline $\mathrm{CeO}_{2} \mathrm{NPs}$ & Sonochemical & [116] \\
\hline $\mathrm{CeO}_{2} \mathrm{NPs}$ & Sonochemical & [117] \\
\hline $\mathrm{Fe}_{3} \mathrm{O}_{4} \mathrm{NPs}$ & Solvothermal & {$[118]$} \\
\hline $\mathrm{Fe}_{3} \mathrm{O}_{4} \mathrm{NPs}$ & Solvothermal & {$[10]$} \\
\hline $\mathrm{MnO}_{2} \mathrm{NPs}$ & Microemulsion & [119] \\
\hline $\mathrm{MnO}_{2}$ NPs & Microemulsion & [120] \\
\hline CuO NPs & Microwave-assisted & [121] \\
\hline $\mathrm{Fe}_{2} \mathrm{O}_{3}$ and $\mathrm{Fe}_{3} \mathrm{O}_{4} \mathrm{NPs}$ & Microwave-assisted & [122] \\
\hline $\mathrm{ZrO}_{2} \mathrm{NPs}$ & Laser ablation & [123] \\
\hline $\mathrm{ZrO}_{2} \mathrm{NPs}$ & Laser ablation & {$[124]$} \\
\hline $\mathrm{CeO}_{2} \mathrm{NPs}$ & Combustion & [81] \\
\hline $\mathrm{CeO}_{2} \mathrm{NPs}$ & Combustion & {$[125]$} \\
\hline $\mathrm{SnO}_{2} \mathrm{NPs}$ & Template & [126] \\
\hline $\mathrm{TiO}_{2} \mathrm{NPs}$ & Template & [127] \\
\hline $\mathrm{CuO} \mathrm{NPs}$ & Green & [128] \\
\hline ZnO NPs & Green & [129] \\
\hline ZnO NPs & Green & [130] \\
\hline $\mathrm{TiO}_{2} \mathrm{NPs}$ & Green & [131] \\
\hline
\end{tabular}

\section{Nanocomposite Materials of Metal Oxides Used in the Degradation of Organic Dyes}

Nanocomposites combine different materials in which at least one of the materials has particle sizes 1-100 nm. Nanocomposite materials have gained a lot of attention due to their improved physical and chemical characteristics. Such materials are suitable for different functional and structural applications in science and technology due to their improved properties, i.e., good mechanical strength, porosity, toughness, electrical and thermal conductivities, dispersibility, and high mobility [132-137]. They have been used to remediation inorganic and organic pollutants, gas sensing, electronic devices, biomedical fields, photocatalytic degradation of organic dyes, etc. The metal oxide-based nanocomposites with advanced surface features, stability, controlled structural and surface features are feasible in the photochemical degradation of organic pollutants. Due to high photodegradation capabilities, controlled bandgap, and efficient synthetic approaches, these materials have been potentially utilized in the photochemical degradation of organic dyes [133-138]. 
Table 2. Some metal oxide-based nanocomposites are used in the photodegradation of dyes.

Metal oxide-based nanocomposites

\begin{tabular}{|c|c|c|c|}
\hline \multicolumn{2}{|c|}{ Metal oxide-based nanocomposites } & Dye degraded & References \\
\hline \multirow{10}{*}{$\begin{array}{c}\text { Graphene } \\
\text { oxide/metal oxide }\end{array}$} & Graphene oxide/ $\mathrm{ZnO}$ & Rhodamine B & {$[132]$} \\
\hline & Graphene oxide/ $/ \mathrm{TiO}_{2}$ & Rhodamine B and acid green 25 & [133] \\
\hline & Graphene oxide/ $/ \mathrm{TiO}_{2}$ & Rhodamine B & [134] \\
\hline & Graphene oxide/CuO & Methylene blue & [135] \\
\hline & Graphene oxide/CuO & Methylene blue & {$[136]$} \\
\hline & Graphene oxide $/ \mathrm{Fe}_{3} \mathrm{O}_{4}$ & Methylene blue & [137] \\
\hline & $\begin{array}{c}\text { Graphene oxide/TiO } \\
\text { and reduced } \mathrm{Graphene} \\
\text { oxide } / \mathrm{TiO}_{2} \\
\end{array}$ & Eosin Y and methylene dyes & {$[138]$} \\
\hline & Graphene oxide $/ \mathrm{SnO}_{2}$ & Methylene blue & {$[139]$} \\
\hline & $\begin{array}{l}\text { Reduced Graphene } \\
\text { oxide/CdO/SnO }\end{array}$ & $\begin{array}{l}\text { Malachite green (MG) and Congo } \\
\text { red }(\mathrm{CR})\end{array}$ & {$[140]$} \\
\hline & $\begin{array}{l}\text { Reduced Graphene } \\
\text { oxide } / \mathrm{TiO}_{2} / \mathrm{Co}_{3} \mathrm{O}_{4}\end{array}$ & Methylene blue and crystal violet & [141] \\
\hline \multirow{7}{*}{$\begin{array}{c}\text { Polymer/metal } \\
\text { oxide }\end{array}$} & Polyaniline $/ \mathrm{TiO}_{2}$ & Red azo dye (RR45) & [142] \\
\hline & Polyaniline/ZnO & $\begin{array}{l}\text { Malachite green and methylene } \\
\text { blue }\end{array}$ & [143] \\
\hline & $\begin{array}{c}\text { Poly }(3,4- \\
\text { ethylenedioxythiophene) } \\
\text { (PEDOT)/ZnO }\end{array}$ & Reactive Red 45 (RR45) & [144] \\
\hline & Polythiophene/ $\mathrm{TiO}_{2}$ & Methyl orange & {$[145]$} \\
\hline & $\begin{array}{c}\text { Polymethyl } \\
\text { methacrylate } / \mathrm{TiO}_{2}\end{array}$ & Methylene blue & [146] \\
\hline & $\begin{array}{c}\text { Polymethyl } \\
\text { methacrylate/ZnO }\end{array}$ & Methylene blue & {$[147]$} \\
\hline & $\begin{array}{c}\text { Poly }(3- \\
\text { hexylthiophene }) / \mathrm{TiO}_{2}\end{array}$ & Methyl orange & [148] \\
\hline \multirow[t]{6}{*}{ Metal/metal oxide } & $\mathrm{Ag} / \mathrm{ZnO}$ & Congo red & [149] \\
\hline & $\mathrm{Cu}-\mathrm{TiO}_{2} / \mathrm{CuO}$ & Methylene blue & {$[150]$} \\
\hline & $\mathrm{Zn} / \mathrm{SnO}_{2}$ & Methylene blue & {$[151,152]$} \\
\hline & $\mathrm{Ag} / \mathrm{TiO}_{2}$ & Methylene blue & {$[153]$} \\
\hline & $\mathrm{Co} / \mathrm{ZnO}$ & Malachite green & [154] \\
\hline & $\mathrm{Co} / \mathrm{ZnO}$ & Methyl orange & {$[155]$} \\
\hline \multirow{9}{*}{ Metal oxide/silica } & $\mathrm{Fe}_{3} \mathrm{O}_{4} / \mathrm{SiO}_{2}$ & Methylene blue & {$[10]$} \\
\hline & $\mathrm{Fe}_{3} \mathrm{O}_{4} / \mathrm{SiO}_{2}$ & Procion Red MX-5B & [156] \\
\hline & $\mathrm{ZnO} / \mathrm{SiO}_{2}$ & Methylene blue & {$[157]$} \\
\hline & $\mathrm{ZnO} / \mathrm{SiO}_{2}$ & Rhodamine B & {$[158]$} \\
\hline & $\mathrm{TiO}_{2} / \mathrm{SiO}_{2}$ & Malachite green & [159] \\
\hline & $\mathrm{SnO}_{2} / \mathrm{SiO}_{2}$ & Orange II & {$[160]$} \\
\hline & $\mathrm{SnO}_{2} / \mathrm{SiO}_{2}$ & Rhodamine B and Crystal violet & [161] \\
\hline & $\mathrm{ZrO}_{2} / \mathrm{SiO}_{2}$ & Rhodamine B & [162] \\
\hline & $\mathrm{ZrO}_{2} / \mathrm{SiO}_{2}$ & Methylene blue & {$[163]$} \\
\hline \multirow{6}{*}{$\begin{array}{c}\text { Metal oxide/metal } \\
\text { oxide }\end{array}$} & $\mathrm{CuO} / \mathrm{ZnO}$ & Congo red & {$[164]$} \\
\hline & $\mathrm{Cu}_{2} \mathrm{O}-\mathrm{CuO} / \mathrm{TiO}_{2}$ & Reactive blue 49 (RB 49) & {$[165]$} \\
\hline & $\mathrm{CuO} / \mathrm{TiO}_{2}$ & Rhodamine B & [166] \\
\hline & $\mathrm{CuO} / \mathrm{TiO}_{2}$ & Methylene blue & {$[167]$} \\
\hline & $\mathrm{Fe}_{3} \mathrm{O}_{4} / \mathrm{ZrO}_{2}$ & Methyl red & [168] \\
\hline & $\mathrm{Fe}_{3} \mathrm{O}_{4} / \mathrm{ZrO}_{2}$ & Methyl orange & [169] \\
\hline \multirow{6}{*}{$\begin{array}{c}\text { Metal } \\
\text { oxide/biomaterials }\end{array}$} & $\begin{array}{c}\mathrm{TiO}_{2} / \text { Chitosan-acrylic } \\
\text { acid }\end{array}$ & Malachite green & {$[170]$} \\
\hline & $\mathrm{Fe}_{3} \mathrm{O}_{4} /$ Chitosan & X-3B dye & [171] \\
\hline & $\begin{array}{l}\text { Carbon black-cellulose } \\
\text { acetate/ZnO }\end{array}$ & $\begin{array}{l}\text { Congo red, methyl orange and } \\
\text { methylene blue }\end{array}$ & {$[172]$} \\
\hline & $\mathrm{MnO}_{2} /$ cellulose & Indigo carmine & [173] \\
\hline & $\mathrm{ZnO} /$ Cellulose & Rhodamine B & [174] \\
\hline & $\begin{array}{l}\mathrm{ZnO} / \text { Cellulose } \\
\text { nanofiber }\end{array}$ & Methylene blue & [175] \\
\hline
\end{tabular}


Some metal oxide-based nanocomposites such as Graphene oxide/metal oxide, polymer/metal oxide, metal/metal oxide, metal oxide/silica, metal oxide/metal oxide, and metal oxide/biomaterials were successfully used in the photodegradation of different dyes from aqueous solutions [132-175] (Table 2).

\section{Characterisation Techniques for Metal Oxide Nanoparticles and their Composite Materials}

Various characterization techniques were used in the exploration of different physical and chemical features of metal oxide nanoparticles and their composite materials. These properties are concerned with surfaces, functionality, behavior, shapes, sizes, arrangement of particles, dispersion, aggregations, elemental composition, etc. The commonly used techniques are Fourier transform infrared spectroscopy (FTIR), X-ray photoelectron spectroscopy (XPS), UV-Visible, Scanning electron microscopy (SEM), Transmission electron microscopy (TEM), Dynamic light scattering (DLS), Zeta-potential, Atomic absorption spectroscopy (AAS), Energy-dispersive X-ray spectroscopy (EDAX), X-ray diffractometry (XRD) and Atomic force microscopy (AFM). Briefly, these analytical techniques can be divided into three categories, i.e., functional property, surface morphology, and other techniques (Table 3) [176-187].

Table 3. Common characterization techniques used to characterize metal oxide nanoparticles and their composite materials.

\begin{tabular}{|c|c|c|}
\hline \multicolumn{2}{|c|}{ Techniques } & Applications \\
\hline \multirow{6}{*}{$\begin{array}{l}\text { Analysis for functional } \\
\text { properties }\end{array}$} & X-ray diffractometry (XRD) & $\begin{array}{l}\text { Crystalline and amorphous } \\
\text { behavior }\end{array}$ \\
\hline & $\begin{array}{l}\text { Energy dispersive X-ray } \\
\text { spectroscopy (EDAX) }\end{array}$ & $\begin{array}{l}\text { Elemental composition in the } \\
\text { nanomaterials }\end{array}$ \\
\hline & $\begin{array}{l}\text { Atomic absorption spectroscopy } \\
\text { (AAS) }\end{array}$ & $\begin{array}{l}\text { Determination of concentrations } \\
\text { of different elements in the } \\
\text { nanomaterials }\end{array}$ \\
\hline & $\begin{array}{l}\text { X-ray photoelectron spectroscopy } \\
\text { (XPS) }\end{array}$ & Oxidation state \\
\hline & UV-Visible spectroscopy & Light extinction \\
\hline & $\begin{array}{c}\text { Fourier transform infrared } \\
\text { spectroscopy (FTIR) }\end{array}$ & $\begin{array}{l}\text { Presence of specific functional } \\
\text { groups in the nanomaterials }\end{array}$ \\
\hline \multirow{3}{*}{$\begin{array}{l}\text { Analysis for surface } \\
\text { morphology }\end{array}$} & $\begin{array}{l}\text { Scanning electron microscopy } \\
(\text { SEM) }\end{array}$ & \multirow{3}{*}{$\begin{array}{l}\text { Morphological features, surface } \\
\text { area, and particle sizes }\end{array}$} \\
\hline & $\begin{array}{l}\text { Transmission electron microscopy } \\
\text { (TEM) }\end{array}$ & \\
\hline & Atomic force microscopy (AFM) & \\
\hline \multirow[t]{2}{*}{ Other analysis } & Dynamic light scattering (DLS) & \multirow[t]{2}{*}{ Surface charges and particle sizes } \\
\hline & Zeta-potential & \\
\hline
\end{tabular}

\section{Conclusions}

The present article has discussed the process of photocatalysis and utilization of some efficient metal oxides and their composite-based photocatalyst in the degradation of different dyes from aqueous solutions under suitable irradiations. The used synthetic approaches have also been illustrated in this article. For large-scale operations of wastewater treatment, costeffective, stable, and eco-friendly metal oxide-based photocatalysts should be designed. The choice of a suitable photocatalyst should be based on their cost, safety, bandgap, high ability to work under sunlight or other visible light, efficiency, and easy recovery and reusability. 


\section{Funding}

This research received no external funding.

\section{Acknowledgments}

I am thankful to Uttaranchal University Dehradun (India) for motivational and technical help during the necessary work of the article.

\section{Conflicts of Interest}

The authors declare that they have no conflict of interest for the publications of the manuscript.

\section{References}

1. Shrivastava, S.; Dash, D. Applying Nanotechnology to Human Health: Revolution in Biomedical Sciences. J. Nanotech. 2009, https://doi.org/10.1155/2009/184702.

2. Rangasamy, M. Nano Technology: A Review. J. Appl. Pharmac. Sci. 2011, 01, 8-16.

3. Chavali, M.S.; Nikolova, M.P. Metal oxide nanoparticles and their applications in nanotechnology. SN Appl. Sci. 2019, https://doi.org/10.1007/s42452-019-0592-3.

4. Joshi, N.C.; Prakash, Y. Leaves extract-based biogenic synthesis of cupric oxide nanoparticles, characterizations, and antimicrobial activity. Asian J. Pharmac Clinical Res. 2019, 12, 288-291.

5. Joshi, N.C.; Chhabra, J. Biological synthesis of silver nanoparticles using the tuberous root extract of Ipomoea batatas and their characterisations and antibacterial activity. Asian J. Pharmac. Clinical Res. 2019, 12, 300303, https://doi.org/10.22159/ajpcr.2019.v12i6.33561.

6. Joshi, N.C.; Malik, S.; Gururani, P. Utilisation of Polypyrrole/ZnO Nanocomposite in the adsorptive removal of $\mathrm{Cu} 2+, \mathrm{Pb} 2+$ and $\mathrm{Cd} 2+$ ions from wastewater. Letters App. Nano Biosci. 2021, 10, $2339-2351$, https://doi.org/10.33263/LIANBS103.23392351.

7. Joshi, N.C.; Joshi, E.; Singh, A. Biological Synthesis, Characterisations and Antimicrobial activities of manganese dioxide (MnO2) nanoparticles. Res. J. Pharm. Techn. 2020, 13, 135-140, https://doi.org/10.5958/0974-360X.2020.00027.X.

8. Dontsova, T.A.; Nahirniak, S.V.; Astrelin, I.M. Metaloxide Nanomaterials and Nanocomposites of Ecological Purpose. J. Nanomate. 2019, https://doi.org/10.1155/2019/5942194.

9. Kavithayeni, V.; Geetha, K.; Akash Prabhu, S. A review on dye reduction mechanism using nano adsorbents in waste water. Intern. J. Recent Techn. Engin. 2019, 7, 332-339.

10. Joshi, N.C.; Gaur, A.; Singh, A. Synthesis, Characterisations, Adsorptive Performances and Photocatalytic Activity of $\mathrm{Fe} 3 \mathrm{O} 4-\mathrm{SiO} 2$ Based Nanosorbent ( $\mathrm{Fe} 3 \mathrm{O} 4-\mathrm{SiO} 2 \mathrm{BN})$. J. Inorg. Organomet. Polym. Mater. 2020, 30, 4416-4425, https://doi.org/10.1007/s10904-020-01622-6.

11. Lellis, B.; Fávaro-Polonio, C.Z.; Pamphile, J.A.; Polonio. J.C. Effects of textile dyes on health and the environment and bioremediation potential of living organisms. Biotech. Res. Innov. 2019, 3, 275-290, https://doi.org/10.1016/j.biori.2019.09.001.

12. Singh, K.; Arora, S. Removal of synthetic textile dyes from wastewaters: a critical review on present treatment technologies. Critical Rev. Environ. Sci. Techn. 2011, 41, 807-878, https://doi.org/10.1080/10643380903218376.

13. Bhatia, D.; Sharma, N.R.; Singh, J.; Kanwar, R.S. Biological methods for textile dye removal from wastewater: A review. Critical Rev. Environ. Sci. Techn. 2017, 47, 1836-1876, https://doi.org/10.1080/10643389.2017.1393263.

14. Zhu, P.; Ren, Z.; Wang, R.; Duan, M.; Xie, L.; Xu, J.; Tian, Y. Preparation and visible photocatalytic dye degradation of Mn-TiO2/sepiolite photocatalysts. Front. Mater. Sci. 2020, 14, 33-42, https://doi.org/10.1007/s11706-020-0486-8.

15. Anwer, H.; Mahmood, A.; Lee, J.; Kim, K.H.; Park, J.W.; Yip, A.C.K. Photocatalysts for degradation of dyes in industrial effluents: Opportunities and challenges. Nano. Res. 2019, 12, 955-972, https://doi.org/10.1007/s12274-019-2287-0.

16. Khan, M.M.; Adil, S.F.; Al-Mayouf, A. Metal oxides as photocatalysts. J. Saudi Chem. Soc. 2015, 19, 462464, https://doi.org/10.1016/j.jscs.2015.04.003. 
17. Zhu, D.; Zhou, Q. Action and mechanism of semiconductor photocatalysis on degradation of organic pollutants in water treatment: A review. Environ. Nanotech. Mon. Manag. 2019, 12, 100255, https://doi.org/10.1016/j.enmm.2019.100255.

18. Regmi, C.; Joshi, B.; Ray, S.K.; Gyawali, G.; Pandey, R.P. Understanding mechanism of photocatalytic microbial decontamination of environmental wastewater. Front. Chem. 2018, 6, 33, https://doi.org/10.3389/fchem.2018.00033.

19. Zhang, J.; Tian, B.; Wang, L.; Xing, M.; Lei, J. Mechanism of Photocatalysis. In: Photocatalysis. Lecture Notes in Chemistry: Springer, Singapore 2018, 100, 1-15, https://doi.org/10.1007/978-981-13-2113-9_1.

20. Hassaan, M.A.; El Nemr, A.; Health and environmental impacts of dyes: mini review. American J. Environ. Sci. Engin. 2017, 1, 64-67.

21. Health and Safety Executive, HSE Dyes and chemicals in textile finishing: An introduction. Dyeing and Finishing Information Sheet No 1- HSE information sheet 2016. https://assets.publishing.service.gov.uk/media/57a08cc9e5274a27b2001415/R8161-Safety.pdf.

22. Elliott, A.; Hanby, W.E.; Malcolm, B.R. The near infra-red absorption spectra of natural and synthetic fibres. Br. J. Appl. Phys. 1954, 5, 377.

23. Lodhi, R.S.; Lal, N. Dyes and pigments manufacturing industrial waste water treatment methodology. Intern. Res. J. Engin. Techn. 2017, 4, 121.

24. Kudaibergenov, S.; Koetz, J.; Nuraje, N. Nanostructured hydrophobic polyampholytes: self-assembly, stimuli-sensitivity, and application. Adv. Compos. Hybrid Mater. 2018, 1, 649-684, https://doi.org/10.1007/s42114-018-0059-9.

25. Markies, P.R.; Moonen, J.P.; Colin, P.O.; Evers, R.W.N.; Van Den Beucken, F.J.H.M.; Peng, K. Aqueous Inkjet Primering Composition Providing Both Pinning and Ink Spreading Functionality, Patent Application No. 15/938,893, United States, 28 March 2018.

26. Khehra, M.S.; Saini, H.S.; Sharma, D.K.; Chadha, B.S.; Chimni, S.S. Biodegradation of azo dye C.I. Acid Red 88 by an anoxic-aerobic sequential bioreactor. Dyes Pigm. 2006, 70, 1-7, https://doi.org/10.1016/j.dyepig.2004.12.021.

27. Popli, S.; Patel, U.D. Destruction of azo dyes by anaerobic-aerobic sequential biological treatment: a review. Int. J. Environ. Sci. Technol. 2015, 12, 405-420, https://doi.org/10.1007/s13762-014-0499-X.

28. Yaseen, D.A.; Scholz, M. Shallow pond systems planted with Lemna minor treating azo dyes. Ecol. Eng. 2016, 94, 295-305, https://doi.org/10.1016/j.ecoleng.2016.05.081.

29. Sharma, K.P.; Sharma, S.; Sharma, S.; Singh, P.K.; Kumar, S.; Grover, R.; Sharma, P.K. A comparative study on characterization of textile wastewaters (untreated and treated) toxicity by chemical and biological tests. Chemos. 2007, 69, 48-54, https://doi.org/10.1016/j.chemosphere.2007.04.086.

30. Sekomo, C.B.; Rousseau, D.P.L.; Saleh, S.A.; Lens, P.N.L. Heavy metal removal in duckweed and algae ponds as a polishing step for textile wastewater treatment. Ecol. Eng. 2012, 44, 102-110, https://doi.org/10.1016/j.ecoleng.2012.03.003.

31. Dos Santos, A.B.; Cervantes, F.J.; Van Lier, J.B. Review paper on current technologies for decolourisation of textile wastewaters: Perspectives for anaerobic biotechnology. Bioresour. Technol. 2007, 98, 2369-2385, https://doi.org/10.1016/j.biortech.2006.11.013.

32. Shah, M.P.; Patel, K.A.; Nair, S.S.; Darji, A.M. Optimization of environmental parameters on microbial degradation of Reactive Black dye. J. Bioremed. Biodegrad. 2013, 4, 10-15.

33. Benkhaya, S.; El Harfi, S.; El Harfi, A. Classifications, properties and applications of textile dyes: A review. Appl. J. Envir. Eng. Sci. 2017, 3, 311-320, https://doi.org/10.48422/IMIST.PRSM/ajees-v3i3.9681.

34. Singh, P.; Abdullah, M.M.; Ikram, S. Role of nanomaterials and their applications as photocatalyst and sensors: A review. Nano Res. Appl. 2016, 2, 1-10.

35. Mohamed, R.M.; McKinney, D.L.; Sigmund, W.M. Enhanced nanocatalysts. Mate. Sci. Engin. 2012, 73, 113, https://doi.org/10.1016/j.mser.2011.09.001.

36. Joshi, N.C.; Congthak, R.; Gururani, P. Synthesis, adsorptive performances and photocatalytic activity of graphene oxide/TiO2 (GO/TiO2) nanocomposite-based adsorbent. Nanotech. Environ. Engin. 2020, 5, 1-13, https://doi.org/10.1007/s41204-020-00085-x.

37. Andrade, G.R.S.; Nascimento, C.C.; Lima, Z.M.; Teixeira-Neto, E.; Costa, L.P.; Gimenez, I.F. Star-shaped $\mathrm{ZnO} / \mathrm{Ag}$ hybrid nanostructures for enhanced photocatalysis and antibacterial activity. Appl. Surf. Sci. 2017, 399, 573-582, https://doi.org/10.1016/j.apsusc.2016.11.202.

38. Friehs, E.; AlSalka, Y.; Jonczyk, R.; Lavrentieva, A.; Jochums, A.; Walter, J.G.; Stahl, F.; Scheper, T.; Bahnemann, D. Toxicity, phototoxicity and biocidal activity of nanoparticles employed in photocatalysis. $J$. 


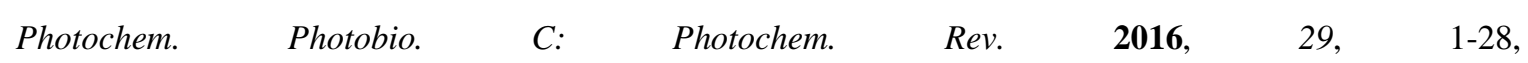
https://doi.org/10.1016/j.jphotochemrev.2016.09.001.

39. Helal, A.; Harraz, F.A.; Ismail, A.A.; Sami, T.M.; Ibrahim, I.A. Hydrothermal synthesis of novel heterostructured Fe2O3/Bi2S3 nanorods with enhanced photocatalytic activity under visible light. Appl. Catal. B: Environ. 2017, 213, 18-27, https://doi.org/10.1016/j.apcatb.2017.05.009.

40. Li, X.; Wang, L.; Zhang, L.; Zhuo, S. A facile route to the synthesis of magnetically separable $\mathrm{BiOBr} / \mathrm{NiFe} 2 \mathrm{O} 4$ composites with enhanced photocatalytic performance. Appl. Surf. Sci. 2017, 419, 586-594, http://doi.org/10.1016/j.apsusc.2017.05.013.

41. Nazim, S.; Kousar, T.; Shahid, M.; Khan, M.A.; Nasar, G.; Sher, M.; Warsi, M.F. New grapheneCoxZn1-xFe2O4 nano-heterostructures: magnetically separable visible light photocatalytic materials. Ceram. Intern. 2016, 42, 7647-7654, http://doi.org/10.1016/j.ceramint.2016.01.177.

42. Zhang, D.; Pu, X.; Gao, Y.; Su, C.; Li, H.; Li, H.; Hang, W. One-step combustion synthesis of CoFe2O4graphene hybrid materialsfor photodegradation of methylene blue. Mater. Lett. 2013, 113, 179-181, https://doi.org/10.1016/j.matlet.2013.09.088.

43. Hisatomi, T.; Kubota, J.; Domen, K. Recent advances in semiconductors for photocatalytic and photoelectrochemical water splitting. Chem. Soc. Rev. 2014, 43, 7520-7535, https://doi.org/10.1039/C3CS60378D.

44. Hoffmann, M.R.; Martin, S.T.; Choi, W.; Bahnemann, D.W. Environmental applications of semiconductor photocatalysis. Chem. Rev. 1995, 95, 69-96, https://doi.org/10.1021/cr00033a004.

45. Danish, M.S.S.; Bhattacharya, A.; Stepanova, D.; Mikhaylov, A.; Grilli, M.L.; Khosravy, M.; Senjyu, T. A Systematic Review of Metal Oxide Applications for Energy and Environmental Sustainability. Metals. 2020, 10, 1604, http://dx.doi.org/10.3390/met10121604.

46. Nunes, D.; Pimentel, A.; Santos, L.; Barquinha, P.; Pereira, L.; Fortunato, E.; Martins, R. Structural, optical, and electronic properties of metal oxide nanostructures. Met. Oxide Nanostruct. 2019, 59-102 https://doi.org/10.1016/B978-0-12-811512-1.00003-5.

47. Gautam, S.; Agrawal, H.; Thakur, M.; Akbari, A.; Sharda, H.; Kaur, R.; Amini, M. Metal oxides and metal organic frameworks for the photocatalytic degradation: A review. J. Environ. Chem. Eng. 2020, 8, 103726, https://doi.org/10.1016/j.jece.2020.103726.

48. Arora, A.K.; Jaswal, V.S.; Singh, K.; Singh, R. Applications of metal/mixed metal oxides as photocatalyst: (A review). Orient. J. Chem 2016, 32, 2035, http://dx.doi.org/10.13005/ojc/320430.

49. Shinde, D.R.; Tambade, P.S.; Chaskar, M.G.; Gadave, K.M. Photocatalytic degradation of dyes in water by analytical reagent grades $\mathrm{ZnO}, \mathrm{TiO} 2$ and $\mathrm{SnO} 2$ : a comparative study. Drink, Water Eng. Sci. 2017, 10, 109117, https://doi.org/10.5194/dwes-10-109-2017.

50. Chong, M.N.; Jin, B.; Chow, C.W.K.; Saint, C. Recent developments in photocatalytic water treatment technology: a review. Water Res. 2010, 44, 2997-3027 https://doi.org/10.1016/j.watres.2010.02.039.

51. Cao, D.; Gong, S.; Shu, X.; Zhu, D.; Liang, S. Preparation of ZnO nanoparticles with high dispersibility based on oriented attachment (OA) process. Nanoscale Res. Lett. 2019, 14, 1-11, https://doi.org/10.1186/s11671019-3038-3.

52. Sabir, S.; Arshad, M.; Chaudhari, S.K. Zinc oxide nanoparticles for revolutionizing agriculture: synthesis and applications. The Scien. World J. 2014, https://doi.org/10.1155/2014/925494.

53. Bhatia, S.; Verma, N. Photocatalytic activity of $\mathrm{ZnO}$ nanoparticles with optimization of defects. Mater. Res. Bull. 2017, 95, 468-476, https://doi.org/10.1016/j.materresbull.2017.08.019.

54. Tayeb, A.M.; Tony, M.A.; Ismaeel, E.K. Engineered nanostructured $\mathrm{ZnO}$ for water remediation: operational parameters effect, Box-Behnken design optimization and kinetic determinations. Appl. Water Sci. 2019, 9, 1-11, https://doi.org/10.1007/s13201-019-0921-0.

55. Bibi, I.; Kamal, S.; Abbas, Z.; Atta, S.; Majid, F.; Jilani, K.; Hussain, A.I.; Kamal, A.; Nouren, S.; Abbas, A. A new approach of photocatalytic degradation of remazol brilliant blue by environment friendly fabricated zinc oxide nanoparticle. Int. J. Environ. Sci. Technol. 2020, 17, 1765-1772, https://doi.org/10.1007/s13762019-02586-y.

56. Rodrigues, J.; Hatami, T.; Rosa, J.M.; Tambourgi, E.B.; Mei, L.H.I. Photocatalytic degradation using ZnO for the treatment of RB 19 and RB 21 dyes in industrial effluents and mathematical modeling of the process. Chem. Engin. Res. 2020, 153, 294-305, https://doi.org/10.1016/j.cherd.2019.10.021.

57. Chijioke-Okere, M.O.; Okorocha, N.J.; Anukam, B.N.; Oguzie, E.E. Photocatalytic degradation of a basic dye using zinc oxide nanocatalyst. Int. Lett. Chem. Phys. Astron. 2019, 81, 18-26, https://doi.org/10.18052/www.scipress.com/ILCPA.81.18. 
58. Sungur, Ş. Titanium Dioxide Nanoparticles. In Handbook of Nanomaterials and Nanocomposites for Energy and Environmental Applications. Springer, Cham, 2020, 1-18, https://doi.org/10.1007/978-3-030-11155-7_91.

59. Haider, A.J.; Jameel, Z.N.; Al-Hussaini, I.H.M. Review on: Titanium Dioxide Applications, Energy Proce. 2019, 157, 17-29, https://doi.org/10.1016/j.egypro.2018.11.159.

60. Beydoun, D.; Amal, R.; Low, G.; McEvoy, S. Role of nanoparticles in photocatalysis. J. Nanoparticle Res. 1999, 1, 439-458, https://doi.org/10.1023/A:1010044830871.

61. Yin, B.; Wang, J.; Xu, W.; Long, D.; Qiao, W.; Ling, L. Preparation of TiO2/mesoporous carbon composites and their photocatalytic performance for methyl orange degradation. New Carb. Mater. 2013, 28, 47-54, https://doi.org/10.1016/S1872-5805(13)60064-5.

62. Nam, Y.; Lim, J.H.; Ko, K.C.; Lee, J.Y. Photocatalytic activity of TiO2 nanoparticles: a theoretical aspect. J. Mater. Chem. A. 2019, 7, 13833-13859, https://doi.org/10.1039/C9TA03385H.

63. Gautam, A.; Kshirsagar, A.; Biswas, R.; Banerjee, S.; Khanna, P.K. Photodegradation of organic dyes based on anatase and rutile $\mathrm{TiO} 2$ nanoparticles. R.S.C. Adv. 2016, 6, 2746-2759, https://doi.org/10.1039/C5RA20861K .

64. Kaur, H.; Kaur, S.; Singh, J.; Rawat, M.; Kumar, S. Expanding horizon: green synthesis of TiO2 nanoparticles using Carica papaya leaves for photocatalysis application. Mater. Res. Express. 2019, 6, 095034, https://doi.org/10.1088/2053-1591/ab2ec5.

65. Khade, G.V.; Suwarnkar, M.B.; Gavade, N.L.; Garadkar, K.M. Green synthesis of TiO2 and its photocatalytic activity. J. Mater. Sci.: Mater. Electron. 2015, 26, 3309-3315, https://doi.org/10.1007/s10854-015-2832-7.

66. Nabi, G.; Ain, Q.U.; Tahir, M.B.; Nadeem Riaz, K.; Iqbal, T.; Rafique, M.; Hussain, S.; Raza, W.; Aslam, I.; Rizwan, M. Green synthesis of $\mathrm{TiO} 2$ nanoparticles using lemon peel extract: their optical and photocatalytic properties. Intern. J. Environ. Analy. Chem. 2020, 1-9, http://doi.org/10.1080/03067319.2020.1722816.

67. Hirvonen, A.; Nowak, R.; Yamamoto, Y.; Sekino, T.; Niihara, K. Fabrication, structure, mechanical and thermal properties of zirconia-based ceramic nanocomposites. J. Europ. Ceram. Soc. 2006, 26, 1497-1505, https://doi.org/10.1016/j.jeurceramsoc.2005.03.232.

68. Ray, J.C.; Park, D.W.; Ahn, W.S. Chemical synthesis of stabilized nanocrystalline zirconia powders. J. Indus. Engin. Chem. 2006, 12, 142-148.

69. Keiteb, A.S.; Saion, E.; Zakaria, A.; Soltani, N. Structural and optical properties of zirconia nanoparticles by thermal treatment synthesis. J. Nanomat. 2016, https://doi.org/10.1155/2016/1913609.

70. Mansouri, M.; Mozafari, N.; Bayati, B.; Setareshenas, N. Photo-catalytic dye degradation of methyl orange using zirconia-zeolite nanoparticles. Bull. Mater. Sci. 2019, 42, 1-11, https://doi.org/10.1007/s12034-0191933-y.

71. Basahel, S.N.; Ali, T.T.; Mokhtar, M.; Narasimharao, K. Influence of crystal structure of nanosized $\mathrm{ZrO} 2$ on photocatalytic degradation of methyl orange. Nanoscale Res. Lett. 2015, 10, 73, https://doi.org/10.1186/s11671-015-0780-z.

72. Saeed, K.; Sadiq, M.; Khan, I.; Ullah, S.; Ali, N.; Khan, A. Synthesis, characterization, and photocatalytic application of Pd/ZrO2 and Pt/ZrO2. Appl. Water Sci. 2018, 8, 1-6, https://doi.org/10.1007/s13201-018-07097.

73. Ali, A.; Zafar, H.; Zia, M.; ul Haq I.; Phull A.R.; Ali J.S.; Hussain, A. Synthesis, characterization, applications, and challenges of iron oxide nanoparticles. Nanotechnol. Sci. Appl. 2016, 9, 49-67, https://doi.org/10.2147/NSA.S99986.

74. Parhizkar, J.; Habibi, M.H. Synthesis, characterization and photocatalytic properties of Iron oxide nanoparticles synthesized by sol-gel autocombustion with ultrasonic irradiation. Nanochem. Res. 2017, 2, 166-171, https://doi.org/10.22036/NCR.2017.02.002.

75. Długosz, O.; Szostak, K.; Krupiński, M.; Banach, M. Synthesis of Fe3O4/ZnO nanoparticles and their application for the photodegradation of anionic and cationic dyes. Int. J. Environ. Sci. Technol. 2020, 18, 561-574, https://doi.org/10.1007/s13762-020-02852-4.

76. Alagiri, M.; Hamid, S.B.A. Green synthesis of $\alpha-\mathrm{Fe} 2 \mathrm{O} 3$ nanoparticles for photocatalytic application. $J$. Mater. Sci: Mater. Electron. 2014, 25, 3572-3577, https://doi.org/10.1007/s10854-014-2058-0.

77. Rincón Joya, M.; Barba Ortega, J.; Malafatti, J.O.D.; Paris, E.C. Evaluation of photocatalytic activity in water pollutants and cytotoxic response of $\alpha$-Fe2O3 nanoparticles. ACS omega. 2019, 4, 17477-17486.

78. Xu, C.; Qu, X. Cerium oxide nanoparticle: a remarkably versatile rare earth nanomaterial for biological applications. N.P.G. Asia Mater. 2014, 6, 90-90, https://doi.org/10.1038/am.2013.88. 
79. Pouretedal, H.R.; Kadkhodaie, A. Synthetic CeO2 nanoparticle catalysis of methylene blue photodegradation: kinetics and mechanism. Chinese J. Cataly. 2010, 31, 1328-1334, https://doi.org/10.1016/S18722067(10)60121-0.

80. Majumder, D.; Chakraborty, I.; Mandal, K.; Roy, S. Facet-dependent photodegradation of methylene blue using pristine $\mathrm{CeO} 2$ nanostructures. ACS omega. 2019, 4, 4243-4251, https://doi.org/10.1021/acsomega.8b03298.

81. Ravishankar, T.N.; Ramakrishnappa, T.; Nagaraju, G.; Rajanaika, H. Synthesis and characterization of CeO2 nanoparticles via solution combustion method for photocatalytic and antibacterial activity studies. Chem. Open. 2015, 4, 146-154, https://doi.org/10.1002/open.201402046.

82. Wu, M.; Hou, P.; Dong, L.; Cai, L.; Chen, Z.; Zhao, M.; Li, J. Manganese dioxide nanosheets: from preparation to biomedical applications. Intern. J. Nanomed. 2019, 14, 4781, https://doi.org/10.2147/IJN.S207666.

83. Rahmat, M.; Rehman, A.; Rahmat, S.; Bhatti, H.N.; Iqbal, M.; Khan, W.S.; Bajwa, S.Z.; Rahmat, R.; Nazir, A. Highly efficient removal of crystal violet dye from water by $\mathrm{MnO} 2$ based nanofibrous mesh/photocatalytic process. J. Mater. Res. Techn. 2019, 8, 5149-5159, https://doi.org/10.1016/j.jmrt.2019.08.038.

84. Khan, I.; Sadiq, M.; Khan, I.; Saeed, K. Manganese dioxide nanoparticles/activated carbon composite as efficient UV and visible-light photocatalyst. Environ. Sci. Pollut. Res. 2019, 26, 5140-5154, https://doi.org/10.1007/s11356-018-4055-y.

85. Chan, Y.L.; Pung, S.Y.; Sreekantan, S.; Yeoh, F.Y. Photocatalytic activity of $\beta-\mathrm{MnO} 2$ nanotubes grown on PET fibre under visible light irradiation. J. Experim. Nanosci. 2016, 11, 603-618, http://dx.doi.org/10.1080/17458080.2015.1102342.

86. Hamza, M.; Altaf, A.A.; Kausar, S.; Murtaza, S.; Rasool, N.; Gul, R.; Badshah, A.; Zaheer, M.; Ali Shah, S.A.; Zakaria, Z.A.Catalytic removal of alizarin red using chromium manganese oxide nanorods: Degradation and kinetic studies. Catalysts. 2020, 10, 1150, https://doi.org/10.3390/catal10101150.

87. Yecheskel, Y.; Dror, I.; Berkowitz, B. Catalytic degradation of brominated flame retardants by copper oxide nanoparticles. Chemosphere. 2013, 93, 172-177, https://doi.org/10.1016/j.chemosphere.2013.05.026.

88. Aslani, A.; Oroojpour, V. $\mathrm{CO}$ gas sensing of $\mathrm{CuO}$ nanostructures, synthesized by an assisted solvothermal wet chemical route. Physica B: Condensed Matt. 2011, 406, 144-149, https://doi.org/10.1016/j.physb.2010.09.038.

89. Li, Y.; Liang, J.; Tao, Z.; Chen, J. CuO particles and plates: synthesis and gas-sensor application. Mater. Res. Bull. 2008, 43, 2380-2385, https://doi.org/10.1016/j.materresbull.2007.07.045.

90. Ishio, S.; Narisawa, T.; Takahashi, S.; Kamata, Y.; Shibata, S.; Hasegawa, T.; Yan, Z.; Liu, X.; Yamane, H.; Kondo, Y.; Ariake, J. L10 FePt thin films with [0 0 1] crystalline growth fabricated by SiO2 addition-rapid thermal annealing and dot patterning of the films. J. Magn. Magn. Mater. 2012, 324, 295-302, https://doi.org/10.1016/j.jmmm.2010.12.014.

91. Kumar, V.; Masudy-Panah, S.; Tan, C.C.; Wong, T.K.S.; Chi, D.Z.; Dalapati, G.K. Copper oxide based low cost thin film solar cells. Proceedings of the IEEE 5th international nanoelectronics conference (INEC), Singapore, 2-4 January 2013; IEEE: 2013, 443-445, https://doi.org/10.1109/INEC.2013.6466072.

92. Wang, X.; Xu, X.; Choi, S.U.S. Thermal conductivity of nanoparticle-fluid mixture. J. Thermophys. Heat Transf. 1999, 13, 474-480, https://doi.org/10.2514/2.6486.

93. Singh, J.; Kumar, V.; Kim, K.H.; Rawat, M. Biogenic synthesis of copper oxide nanoparticles using plant extract and its prodigious potential for photocatalytic degradation of dyes. Environ. Res. 2019, 177, 108569, https://doi.org/10.1016/j.envres.2019.108569.

94. Sharma, A.; Dutta, R.K. Studies on the drastic improvement of photocatalytic degradation of acid orange-74 dye by TPPO capped $\mathrm{CuO}$ nanoparticles in tandem with suitable electron capturing agents. R.S.C. Adv. 2015, 5, 43815-43823, https://doi.org/10.1039/C5RA04179A.

95. Narasaiah, P.; Mandal, B.K.; Sarada, N.C. Biosynthesis of copper oxide nanoparticles from Drypetes sepiaria leaf extract and their catalytic activity to dye degradation. IOP Conf. Ser.: Mater. Sci. Eng. 2017, 263, 022012, https://doi.org/10.1088/1757-899X/263/2/022012.

96. Chauhan, M.; Kaur, N.; Bansal, P.; Kumar, R.; Srinivasan, S.; Chaudhary, G.R. Proficient Photocatalytic and Sonocatalytic Degradation of Organic Pollutants Using $\mathrm{CuO}$ Nanoparticles. J. Nanomater. 2020, https://doi.org/10.1155/2020/6123178.

97. Sheng Pan, S.; Fung Yu, S.; Xia Zhang, Y.; Yuan Luo, Y.; Wang, S.; Min Xu, J.; Hai Li, G. Crystallite sizemodulated exciton emission in $\mathrm{SnO} 2$ nanocrystalline films grown by sputtering. J. Appl. Phys. 2013, 113, 143104, https://doi.org/10.1063/1.4800896. 
98. Shi, L.; Lin, H. Facile fabrication and optical property of hollow $\mathrm{SnO} 2$ spheres and their application in water treatment. Langmuir. 2010, 26, 18718-18722, https://doi.org/10.1021/la103769d.

99. Wu, S.; Cao, H.; Yin, S.; Liu, X.; Zhang, X. Amino acid-assisted hydrothermal synthesis and photocatalysis of SnO2 nanocrystals. J. Phys. Chem. C. 2009, 113, 17893-17898, https://doi.org/10.1021/jp9068762.

100. Agekyan, V.T. Spectroscopic properties of semiconductor crystals with direct forbidden energy gap. Phys. Status Sol. (A) Appl. Res. 1977, 43, 11-42.

101.Viet, P.V.; Thi, C.M.; Hieu, L.V. The high photocatalytic activity of SnO2 nanoparticles synthesized by hydrothermal method. J. Nanomate. 2016, https://doi.org/10.1155/2016/4231046.

102.Elango, G.; Roopan, S.M. Efficacy of $\mathrm{SnO} 2$ nanoparticles toward photocatalytic degradation of methylene blue dye. J. Photochem. Photobio. B. 2016, 155, 34-38, https://doi.org/10.1016/j.jphotobiol.2015.12.010.

103.Tammina, S.K.; Mandal, B.K.; Kadiyala, N.K. Photocatalytic degradation of methylene blue dye by nonconventional synthesized SnO2 nanoparticles. Environ. Nanotech. Monit. Manag. 2018, 10, 339-350, https://doi.org/10.1016/j.enmm.2018.07.006.

104.Li, Y.; Yang, Q.; Wang, Z.; Wang, G.; Zhang, B.; Zhang, Q.; Yang, D. Rapid fabrication of SnO2 nanoparticle photocatalyst: computational understanding and photocatalytic degradation of organic dye. Inorg. Chem. Front. 2018, 5, 3005-3014, https://doi.org/10.1039/C8QI00688A.

105.Titus, D.; Samuel, E.J.J. Photocatalytic Degradation of Azo Dye Using Biogenic SnO2 Nanoparticles with Antifungal Property: RSM Optimization and Kinetic Study. J. Clust. Sci. 2019, 30, 1335-1345, https://doi.org/10.1007/s10876-019-01585-w.

106. Yong, N.L.; Ahmad, A.; Mohammad, A.W. Synthesis and characterization of silver oxide nanoparticles by a novel method. Int J Sci Eng Res. 2013, 4, 155-158.

107.Shume, W.M.; Murthy, H.C.A.; Zereffa, E.A. A review on synthesis and characterization of Ag2O nanoparticles for photocatalytic applications. J. Chem. 2020, https://doi.org/10.1155/2020/5039479.

108. Stankic, S.; Suman, S.; Haque, F.; Vidic, J. Pure and multi metal oxide nanoparticles: synthesis, antibacterial and cytotoxic properties. J. Nanobiotechnol. 2016, 14, 1-20, https://doi.org/10.1186/s12951-016-0225-6.

109. Korotcenkov, G. Current Trends in Nanomaterials for Metal Oxide-Based Conductometric Gas Sensors: Advantages and Limitations. Part 1: 1D and 2D Nanostructures, Nanomate. 2020, 10, 1392, https://doi.org/10.3390/nano10071392.

110.Buraso, W.; Lachom, V.; Siriya, P.; Laokul, P. Synthesis of TiO2 nanoparticles via a simple precipitation method and photocatalytic performance. Mater. Res. Express. 2018, 5, 115003, https://doi.org/10.1088/20531591/aadbf0.

111.Liu, Z.; Wang, R.; Kan, F.; Jiang, F. Synthesis and characterization of TiO2 nanoparticles. Asian J. Chem. 2014, 26, 655, http://dx.doi.org/10.14233/ajchem.2014.15462.

112.Ibarguen, C.A.; Mosquera, A.; Parra, R.; Castro, M.S.; Rodríguez-Páez, J.E. Synthesis of SnO2 nanoparticles through the controlled precipitation route. Mater. Chem. Phys. 2007, 101, 433-440, https://doi.org/10.1016/j.matchemphys.2006.08.003.

113.Hasnidawani, J.N.; Azlina, H.N.; Norita, H.; Bonnia, N.N.; Ratim, S.; Ali, E.S. Synthesis of ZnO nanostructures using sol-gel method. Procedia Chem. 2016, 19, 211-216, https://doi.org/10.1016/j.proche.2016.03.095.

114. Al Abdullah, K.; Awad, S.; Zaraket, J.; Salame, C. Synthesis of ZnO nanopowders by using sol-gel and studying their structural and electrical properties at different temperature. Energy Procedia. 2017, 119, 565570, https://doi.org/10.1016/j.egypro.2017.07.080.

115.Prasad, K.; Pinjari, D.V.; Pandit, A.B.; Mhaske, S.T. Synthesis of zirconium dioxide by ultrasound assisted precipitation: effect of calcination temperature. Ultrasonics Sonochem. 2011, 18, 1128-1137, https://doi.org/10.1016/j.ultsonch.2011.03.001.

116.Yin, L.; Wang, Y.; Pang, G.; Koltypin, Y.; Gedanken, A. Sonochemical synthesis of cerium oxide nanoparticles_effect of additives and quantum size effect. J. Coll. Inter. Sci. 2002, 246, 78-84, https://doi.org/10.1006/jcis.2001.8047.

117.Alammar, T.; Noei, H.; Wang, Y.; Grünert, W.; Mudring, A.V. Ionic liquid-assisted sonochemical preparation of $\mathrm{CeO} 2$ nanoparticles for $\mathrm{CO}$ oxidation. A.C.S. Sustainable Chem. Eng. 2015, 3, 42-54, https://doi.org/10.1021/sc500387k.

118.Zak, A.K.; Shirmahd, H.; Mohammadi, S.; Banihashemian, S.M. Solvothermal synthesis of porous Fe3O4 nanoparticles for humidity sensor application. Mater. Res. Express. 2020, 7, 025001, https://doi.org/10.1088/2053-1591/ab6e3c. 
119.Devaraj, S.; Munichandraiah, N. Electrochemical supercapacitor studies of nanostructured $\alpha$-MnO2 synthesized by microemulsion method and the effect of annealing. Annealing, J. Electrochem. Soc. 2006, 154, A80-A88, https://doi.org/10.1149/1.2404775.

120.Xu, C.; Li, B.; Du, H.; Kang, F.; Zeng, Y. Electrochemical properties of nanosized hydrous manganese dioxide synthesized by a self-reacting microemulsion method. J. Power Sources. 2008, 180, 664-670, https://doi.org/10.1016/j.jpowsour.2008.02.029.

121. Anand, G.T.; Sundaram, S.J.; Kanimozhi, K.; Nithiyavathi, R.; Kaviyarasu, K. Microwave assisted green synthesis of $\mathrm{CuO}$ nanoparticles for environmental applications. Materials Today: Proceedings. 2021, 36, 427434, https://doi.org/10.1016/j.matpr.2020.04.881.

122.Wang, W.W.; Zhu, Y.J.; Ruan, M.L. Microwave-assisted synthesis and magnetic property of magnetite and hematite nanoparticles. J Nanopart. Res. 2007, 9, 419-426, https://doi.org/10.1007/s11051-005-9051-8.

123.Mahmoud, A.K.; Fadhill, Z.; Al-nassar, S.I.; Husein, F.I.; Akman, E.; Demir, A. Synthesis of zirconia nanoparticles in distilled water solution by laser ablation technique. J. Mate. Sci. Engin. B. 2013, 3, 364-368.

124.Gondal, M.A.; Fasasi, T.A.; Baig, U.; Mekki, A. Effects of oxidizing media on the composition, morphology and optical properties of colloidal zirconium oxide nanoparticles synthesized via pulsed laser ablation in liquid technique. J. Nanosci. Nanotechnol. 2018, 18, 4030-4039, https://doi.org/10.1166/jnn.2018.15244.

125.Mehrizi, M.Z.; Ahmadi, S.; Beygi, R.; Asadi, M. Fabrication of cerium oxide nanoparticles by solution combustion synthesis and their cytotoxicity evaluation. Russ. J. Non-ferrous Metals. 2018, 59, 111-116, https://doi.org/10.3103/S1067821218010170.

126.Zhang, H.; Wang, L.; Tan, Z.; Li, Z.; Ding, G.; Jiao, Z.; Gu, P. Preparation of SnO2 nanoparticles by hard template method for high selectivity gas sensors. J. Nanosci. Nanotechnol. 2011, 11, 11023-11027, https://doi.org/10.1166/jnn.2011.4008.

127.Ojeda, M.; Chen, B.; Leung, D.Y.C.; Xuan, J.; Wang, H. A hydrogel template synthesis of TiO2 nanoparticles for aluminium-ion batteries. Energy Procedia. 2017, 105, 3997-4002, https://doi.org/10.1016/j.egypro.2017.03.836.

128.Siddiqui, H.; Qureshi, M.S.; Haque, F.Z. Biosynthesis of flower-shaped $\mathrm{CuO}$ nanostructures and their photocatalytic and antibacterial activities. Nano-Micro Lett. 2020, 12, 1-11, https://doi.org/10.1007/s40820019-0357-y.

129.Chikkanna, M.M.; Neelagund, S.E.; Rajashekarappa, K.K. Green synthesis of zinc oxide nanoparticles ( $\mathrm{ZnO}$ NPs) and their biological activity. SN Appl. Sci. 2019, 1, 1-10, https://doi.org/10.1007/s42452-018-0095-7.

130.Ezealisiji, K.M.; Siwe-Noundou, X.; Maduelosi, B.; Nwachukwu, N.; Krause, R.W.M. Green synthesis of zinc oxide nanoparticles using Solanum torvum (L) leaf extract and evaluation of the toxicological profile of the $\mathrm{ZnO}$ nanoparticles-hydrogel composite in Wistar albino rats. Int. Nano Lett. 2019, 9, 99-107, https://doi.org/10.1007/s40089-018-0263-1.

131.Thakur, B.K.; Kumar, A.; Kumar, D. Green synthesis of titanium dioxide nanoparticles using Azadirachta indica leaf extract and evaluation of their antibacterial activity. South Afr. J. Bot. 2019, 124, 223-227, https://doi.org/10.1016/j.sajb.2019.05.024.

132. Ramanathan, S.; Selvin, S.P.; Obadiah, A.; Durairaj, A.; Santhoshkumar, P.; Lydia, S.; Ramasundaram, S.; Vasanthkumar, S. Synthesis of reduced graphene oxide/ZnO nanocomposites using grape fruit extract and Eichhornia crassipes leaf extract and a comparative study of their photocatalytic property in degrading Rhodamine B dye. J. Environ. Health Sci. Eng. 2019, 17, 195-207, https://doi.org/10.1007/s40201-01900340-7.

133.Adly, M.S.; El-Dafrawy, S.M.; El-Hakam, S.A. Application of nanostructured graphene oxide/titanium dioxide composites for photocatalytic degradation of rhodamine B and acid green 25 dyes. J. Mater. Res. Techn. 2019, 8, 5610-5622, https://doi.org/10.1016/j.jmrt.2019.09.029.

134.Ali, M.H.H.; Al-Afify, A.D.; Goher, M.E. Preparation and characterization of graphene-TiO2 nanocomposite for enhanced photodegradation of Rhodamine-B dye. The Egyptian J. Aqu. Res. 2018, 44, 263-270, https://doi.org/10.1016/j.ejar.2018.11.009.

135.Ganesan, K.; Jothi, V.K.; Natarajan, A.; Rajaram, A.; Ravichandran, S.; Ramalingam, S. Green synthesis of Copper oxide nanoparticles decorated with graphene oxide for anticancer activity and catalytic applications. Arabian J. Chem. 2020, 13, 6802-6814, https://doi.org/10.1016/j.arabjc.2020.06.033.

136. Yusoff, N.; Huang, N.M.; Muhamad, M.R.; Kumar, S.V.; Lim, H.N.; Harrison, I. Hydrothermal synthesis of $\mathrm{CuO} /$ functionalized graphene nanocomposites for dye degradation. Mater. Lett. 2013, 93, 393-396, https://doi.org/10.1016/j.matlet.2012.10.015. 
137.Zhou, C.; Zhang, W.; Wang, H.; Li, H.; Zhou, J.; Wang, S.; Liu, J.; Luo, J.; Zou, B.; Zhou, J. Preparation of Fe3O4-embedded graphene oxide for removal of methylene blue. Arab. J. Sci. Eng. 2014, 9, 6679-6685, https://doi.org/10.1007/s13369-014-1183-7.

138. Ojha, A.; Thareja, P. Graphene-based nanostructures for enhanced photocatalytic degradation of industrial dyes. Emergent Materials. 2020, 3, 169-180, https://doi.org/10.1007/s42247-020-00081-6.

139.Seema, H.; Kemp, K.C.; Chandra, V.; Kim, K.S. Graphene-SnO2 composites for highly efficient photocatalytic degradation of methylene blue under sunlight. Nanotechn. 2012, 23, 355705, https://doi.org/10.1088/0957-4484/23/35/355705.

140.Sirohi, K.; Kumar, S.; Singh, V.; Chauhan, N.; Vohra, A. Synthesis, characterization and photocatalytic properties of graphene-CdO/SnO2 ternary nanocomposites in visible light. Mate. Res. Expr. 2019, 6, 075901, https://doi.org/10.1088/2053-1591/ab122c.

141.Ranjith, R.; Renganathan, V.; Chen, S.M.; Selvan, N.S.; Rajam, P.S. Green synthesis of reduced graphene oxide supported $\mathrm{TiO} 2 / \mathrm{Co} 3 \mathrm{O} 4$ nanocomposite for photocatalytic degradation of methylene blue and crystal violet. Ceramics Intern. 2019, 45, 12926-12933, https://doi.org/10.1016/j.ceramint.2019.03.219.

142.Gilja, V.; Novaković, K.; Travas-Sejdic, J.; Hrnjak-Murgić, Z.; Kraljić Roković, M.; Žic, M. Stability and synergistic effect of polyaniline/TiO2 photocatalysts in degradation of azo dye in wastewater. Nanomate. 2017, 7, 412, https://doi.org/10.3390/nano7120412.

143.Eskizeybek, V.; Sarı, F.; Gülce, H.; Gülce, A.; Avc1, A. Preparation of the new polyaniline/ZnO nanocomposite and its photocatalytic activity for degradation of methylene blue and malachite green dyes under UV and natural sun lights irradiations. App. Catalysis B: Environ. 2012, 119, 197-206, https://doi.org/10.1016/j.apcatb.2012.02.034.

144.Katančić, Z.; Šuka, S.; Vrbat, K.; Tašić, A.; Hrnjak-Murgić, Z. Synthesis of PEDOT/ZnO Photocatalyst: validation of Photocatalytic activity by degradation of Azo RR45 dye under solar and UV-A irradiation. Chem. Biochem. Eng. Q. 2017, 31, 385-394, https://doi.org/10.15255/CABEQ.2017.1124.

145.Zhu, Y.; Xu, S.; Yi, D. Photocatalytic degradation of methyl orange using polythiophene/titanium dioxide composites. React. Funct. Polym. 2010, 70, 282-287, https://doi.org/10.1016/j.reactfunctpolym.2010.01.007.

146. Ounas, O.; El Foulani, A.A.; Lekhlif, B.; Jamal-Eddine, J. Immobilization of TiO2 into a poly methyl methacrylate (PMMA) as hybrid film for photocatalytic degradation of methylene blue. Materials Today: Proceedings. 2020, 22, 35-40, https://doi.org/10.1016/j.matpr.2019.08.068.

147.Di Mauro, A.; Cantarella, M.; Nicotra, G.; Pellegrino, G.; Gulino, A.; Brundo, M.V.; Privitera, V.; Impellizzeri, G. Novel synthesis of ZnO/PMMA nanocomposites for photocatalytic applications. Sci. Rep. 2017, 7, 1-12, https://doi.org/10.1038/srep40895.

148.Wang, D.; Zhang, J.; Luo, Q.; Li, X.; Duan, Y.; An, J. Characterization and photocatalytic activity of poly (3-hexylthiophene)-modified $\mathrm{TiO} 2$ for degradation of methyl orange under visible light. J. Hazard. Mater. 2009, 169, 546-550, https://doi.org/10.1016/j.jhazmat.2009.03.135.

149. Chauhan, A.; Verma, R.; Kumari, S.; Sharma, A.; Shandilya, P.; Li, X.; Batoo, K.M.; Imran, A.; Kulshrestha, S.; Kumar, R. Photocatalytic dye degradation and antimicrobial activities of Pure and Ag-doped ZnO using Cannabis sativa leaf extract. Sci. Rep. 2020, 10, 1-16, https://doi.org/10.1038/s41598-020-64419-0.

150.Udayabhanu; Reddy, N.L.; Shankar, M.V.; Sharma, S.C.; Nagaraju, G. One-pot synthesis of Cu-TiO2/CuO nanocomposite: Application to photocatalysis for enhanced $\mathrm{H} 2$ production, dye degradation \& detoxification of Cr (VI). Intern. J. Hydrogen Ener. 2020, 45, 7813-7828, https://doi.org/10.1016/j.ijhydene.2019.10.081.

151.Sujatha, K.; Seethalakshmi, T.; Sudha, A.P.; Shanmugasundaram, O.L. Photocatalytic activity of pure, Zn doped and surfactants assisted $\mathrm{Zn}$ doped $\mathrm{SnO} 2$ nanoparticles for degradation of cationic dye. Nano Struct. Nano Obj. 2019, 18, 100305, https://doi.org/10.1016/j.nanoso.2019.100305.

152.Baig, A.B.A.; Rathinam, V.; Ramya, V. Facile fabrication of Zn-doped $\mathrm{SnO} 2$ nanoparticles for enhanced photocatalytic dye degradation performance under visible light exposure. Adv. Comp. Hyb. Mater. 2021, 4, 114-126, https://doi.org/10.1007/s42114-020-00195-9.

153.Singh, J.; Tripathi, N.; Mohapatra, S. Synthesis of Ag-TiO2 hybrid nanoparticles with enhanced photocatalytic activity by a facile wet chemical method. Nano Struc. Nano Obj. 2019, 18, 100266, https://doi.org/10.1016/j.nanoso.2019.100266.

154.Rabie, A.M.; Abukhadra, M.R.; Rady, A.M.; Ahmed, S.A.; Labena, A.; Mohamed, H.S.H.; Betiha, M.A.; Shim, J.J. Instantaneous photocatalytic degradation of malachite green dye under visible light using novel green Co-ZnO/algae composites. Res. Chem. Intermed. 2020, 46, 1955-1973, https://doi.org/10.1007/s11164-019-04074-X. 
155.Adeel, M.; Saeed, M.; Khan, I.; Muneer, M.; Akram, N. Synthesis and Characterization of Co-ZnO and Evaluation of Its Photocatalytic Activity for Photodegradation of Methyl Orange. A.C.S. omega. 2021, 6, 1426-1435, https://doi.org/10.1021/acsomega.0c05092.

156. Wang, H.; Zhang, W.; Zhao, J.; Xu, L.; Zhou, C.; Chang, L.; Wang, L. Rapid decolorization of phenolic azo dyes by immobilized laccase with $\mathrm{Fe} 3 \mathrm{O} 4 / \mathrm{SiO} 2$ nanoparticles as support. Ind. Eng. Chem. Res. 2013, 52, 4401-4407, https://doi.org/10.1021/ie302627c.

157.Soltani, R.D.C.; Shams Khoramabadi, G.; Godini, H.; Noorimotlagh, Z. The application of $\mathrm{ZnO} / \mathrm{SiO} 2$ nanocomposite for the photocatalytic degradation of a textile dye in aqueous solutions in comparison with pure ZnO nanoparticles. Desal. Water Treatm. 2015, 56, 2551-2558, https://doi.org/10.1080/19443994.2014.964781.

158. Shen, X.; Shi, Y.; Shao, H.; Liu, Y.; Zhai, Y. Synthesis and photocatalytic degradation ability evaluation for rhodamine B of ZnO@ SiO2 composite with flower-like structure. Water Sci. Technol. 2019, 80, 1986-1995, https://doi.org/10.2166/wst.2020.020.

159.Yang, J.; Xu, X.; Liu, Y.; Gao, Y.; Chen, H.; Li, H. Preparation of SiO2@ TiO2 composite nanosheets and their application in photocatalytic degradation of malachite green at emulsion interface. Colloids and Surfaces A: Physicochem. Engin. Asp. 2019, 582, 123858, https://doi.org/10.1016/j.colsurfa.2019.123858.

160.Khan, I.; Khan, A.A.; Khan, I.; Usman, M.; Sadiq, M.; Ali, F.; Saeed, K. Investigation of the photocatalytic potential enhancement of silica monolith decorated tin oxide nanoparticles through experimental and theoretical studies. New J. Chem. 2020, 44, 13330-13343, https://doi.org/10.1039/D0NJ00996B.

161.Francis, S.M.A.; Thiruvengadam, V. Catalytic Reduction of Rhodamine B and Crystal Violet using SnO2$\mathrm{SiO} 2$ Nanocomposite Derived from Rice Husk. Intern. Res. J. Engin. Techn. 2020, 7, 2094-2097.

162.Padovini, D.S.S.; Magdalena, A.G.; Capeli, R.G.; Longo, E.; Dalmaschio, C.J.; Chiquito, A.J.; Pontes, F.M. Synthesis and characterization of $\mathrm{ZrO} 2 @ \mathrm{SiO} 2$ core-shell nanostructure as nanocatalyst: Application for environmental remediation of rhodamine B dye aqueous solution. Mate. Chem. Phys. 2019, 233, 1-8, https://doi.org/10.1016/j.matchemphys.2019.05.024.

163. Vaizoğullar, A.İ.; Balci, A.; Uğurlu, M. Synthesis of $\mathrm{ZrO} 2$ and $\mathrm{ZrO} 2 / \mathrm{SiO} 2$ particles and photocatalytic degradation of methylene blue. Indian J. Chem. Sect. A. 2015, 54, 1434-1439.

164. Khairol, N.F.; Sapawe, N.; Danish, M. Photocatalytic Study of ZnO-CuO/ES on Degradation of Congo Red. Mater. Today Proceed. 2019, 19, 1333-1339, https://doi.org/10.1016/j.matpr.2019.11.146.

165.Ajmal, A.; Majeed, I.; Malik, R.N.; Iqbal, M.; Nadeem, M.A.; Hussain, I.; Yousaf, S.; Mustafa, G.; Zafar, M.I.; Nadeem, M.A. Photocatalytic degradation of textile dyes on $\mathrm{Cu} 2 \mathrm{O}-\mathrm{CuO} / \mathrm{TiO} 2$ anatase powders. $J$. Environ. Chem. Engin. 2016, 4, 2138-2146, https://doi.org/10.1016/j.jece.2016.03.041.

166.Date, M.K.; Yang, L.H.; Yang, T.Y.; Wang, K.Y.; Su, T.Y.; Wu, D.C.; Cheuh, Y.L. Three-dimensional $\mathrm{CuO} / \mathrm{TiO} 2$ hybrid nanorod arrays prepared by electrodeposition in AAO membranes as an excellent Fentonlike photocatalyst for dye degradation. Nanoscale Res. Lett. 2020, 15, 1-12, https://doi.org/10.1186/s11671020-3266-6.

167.Abo-El Fadl, M. M. S.; Ali, M.E.A.; Elsayed, F.M.; Abdel-Mottaleb, M.S.A. Use of prepared nano CuO /TiO2 in photocatalytic process for remove organic waste from groundwater, San El-Hager area. Egypt. Int. J. Environ. 2018, 7, 16-29.

168. Khan, I.; Zada, N.; Khan, I.; Sadiq, M.; Saeed, K. Enhancement of photocatalytic potential and recoverability of Fe3O4 nanoparticles by decorating over monoclinic zirconia. J. Environ. Health Sci. Engin. 2020, 18, 1473-1489, https://doi.org/10.1007/s40201-020-00563-z.

169.Davar, F.; Majedi, A.; Abbasi, A. Synthesis of Fe3O4@ ZrO2 core-shell nanoparticles through new approach and its solar light photocatalyst application. J. Mater. Sci.: Mater. Electron. 2017, 28, 4871-4878, https://doi.org/10.1007/s10854-016-6134-5.

170.Bahal, M.; Kaur, N.; Sharotri, N.; Sud, D. Investigations on amphoteric chitosan/TiO2 bionanocomposites for application in visible light induced photocatalytic degradation. Adv. Polym. Technol. 2019, https://doi.org/10.1155/2019/2345631.

171.Adnan, M.A.M.; Phoon, B.L.; Julkapli, N.M. Mitigation of pollutants by chitosan/metallic oxide photocatalyst: a review. J. Clean. Prod. 2020, 261, 121190, https://doi.org/10.1016/j.jclepro.2020.121190.

172.Khan, S.A.; Khan, S.B.; Farooq, A.; Asiri, A.M. A facile synthesis of CuAg nanoparticles on highly porous $\mathrm{ZnO} /$ carbon black-cellulose acetate sheets for nitroarene and azo dyes reduction/degradation. Int. J. Biol. Macromol. 2019, 130, 288-299, https://doi.org/10.1016/j.ijbiomac.2019.02.114. 
173. Oliveira, L.V.F.; Bennici, S.; Josien, L.; Limousy, L.; Bizeto, M.A.; Camilo, F.F. Free-standing cellulose film containing manganese dioxide nanoparticles and its use in discoloration of indigo carmine dye. Carbohydr. Polym. 2020, 230, 115621, https://doi.org/10.1016/j.carbpol.2019.115621.

174.Fu, F.; Gu, J.; Xu, X.; Xiong, Q.; Zhang, Y.; Liu, X.; Zhou, J. Interfacial assembly of ZnO-cellulose nanocomposite films via a solution process: a one-step biomimetic approach and excellent photocatalytic properties. Cellulose. 2017, 24, 147-162, https://doi.org/10.1007/s10570-016-1087-7.

175.Dehghani, M.; Nadeem, H.; Raghuwanshi, V.S.; Mahdavi, H.; Banaszak Holl, M.M.; Batchelor, W. $\mathrm{ZnO} /$ cellulose nanofiber composites for sustainable sunlight-driven dye degradation. A.C.S. Appl. Nano. Mater. 2020, 3, 10284-10295, https://doi.org/10.1021/acsanm.0c02199.

176.Wang, H.; Zhang, W.; Zhao, J.; Xu, L.; Zhou, C.; Chang, L.; Wang, L. Rapid decolorization of phenolic azo dyes by immobilized laccase with $\mathrm{Fe} 3 \mathrm{O} 4 / \mathrm{SiO} 2$ nanoparticles as support. Ind. Eng. Chem. Res. 2013, 52, 4401-4407, https://doi.org/10.1021/ie302627c.

177.Joshi, N.C.; Kaur, K.; Kumar, N.; Bhandari, N.S.; Thakur, A. Synthesis and adsorption applications of PPY/Fe3O4 nanocomposite based material. Nano-Struc. Nano-Obj. 2021, 25, 100669, https://doi.org/10.1016/j.nanoso.2021.100669.

178.Grilli, M.L.; Chevallier, L.; Di Vona, M.L.; Licoccia, S.; Di Bartolomeo, E. Planar electrochemical sensors based on YSZ with WO3 electrode prepared by different chemical routes. Sens. Actuators B Chem. 2005, 111, 91-95, https://doi.org/10.1016/j.snb.2005.06.035.

179.Masetti, E.; Grilli, M.L.; Dautzenberg, G.; Macrelli, G.; Adamik, M. Analysis of the influence of the gas pressure during the deposition of electrochromic WO3 films by reactive r.f. sputtering of W and WO3 target. Sol. Energy Mater. Sol. Cells. 1999, 56, 259-269, https://doi.org/10.1016/S0927-0248(98)00136-6.

180.Grilli, M.L.; Kaabbuathong, N.; Dutta, A.; Di Bartolomeo, E.; Traversa, E. Electrochemical NO2 sensors with WO3 electrodes for high temperature applications. J. Ceram. Soc. Jpn. 2002, 110, 159-162, https://doi.org/10.2109/jcersj.110.159.

181.Upadhyay, R.K.; Soin, N.; Roy, S.S. Role of graphene/metal oxide composites as photocatalysts, adsorbents and disinfectants in water treatment: a review. R.S.C. Adv. 2014, 4, 3823-3851, https://doi.org/10.1039/C3RA45013A.

182.Raizada, P.; Kumari, J.; Shandilya, P.; Dhiman, R.; Singh, V.P.; Singh, P. Magnetically retrievable $\mathrm{Bi} 2 \mathrm{WO} 6 / \mathrm{Fe} 3 \mathrm{O} 4$ immobilized on graphene sand composite for investigation of photocatalytic mineralization of oxytetracycline and ampicillin. Process Saf. Environ. Prot. 2017, 106, 104-116, https://doi.org/10.1016/j.psep.2016.12.012.

183.Sarkar, S.; Ponce, N.T.; Banerjee, A.; Bandopadhyay, R.; Rajendran, S.; Lichtfouse, E. Green polymeric nanomaterials for the photocatalytic degradation of dyes: a review. Environ. Chem. Lett. 2020, 18, 15691580, https://doi.org/10.1007/s10311-020-01021-w.

184.Joshi, N.C.; Malik, N.; Singh, A. Synthesis and characterizations of polythiophene-Al2O3 based nanosorbent and its applications in the removal of $\mathrm{Pb} 2+, \mathrm{Cd} 2+$ and $\mathrm{Zn} 2+$ ions. J Inorg. Organom. Polym. Mater. 2020, 30, 1438-1447, https://doi.org/10.1007/s10904-019-01252-7.

185.Joshi, N.C.; Singh, A. Adsorptive performances and characterisations of biologically synthesised zinc oxide based nanosorbent (ZOBN). Groundw. Sustain. Develop. 2020, 10, 100325, https://doi.org/10.1016/j.gsd.2019.100325.

186.Joshi, N.C.; Chaudhary, N.; Rai, N. Medicinal Plant Leaves Extract Based Synthesis, Characterisations and Antimicrobial Activities of $\mathrm{ZrO} 2$ Nanoparticles (ZrO2 NPs). BioNanoSci. 2021, 11, 497-505, https://doi.org/10.1007/s12668-021-00829-2.

187.Joshi, N.C.; Singh, A. Nano-silver: Biosynthesis, characterisations and antimicrobial activities. Intern. J. Green Herbal Chem. 2018, 7, 467-475. 